\title{
Human-Environment Natural Disasters Interconnection in China: A Review
}

 \\ 1 College of Hydraulic and Environmental Engineering, China Three Gorges University, \\ Yichang 443002, China \\ 2 Department of Petroleum, Koya Technical Institute, Erbil Polytechnic University, Erbil 44001, Kurdistan, Iraq \\ 3 CERIS, Instituto Superior Tecnico, Universidade de Lisboa, 1049-001 Lisbon, Portugal; \\ alban.kuriqi@tecnico.ulisboa.pt \\ 4 School of Technology, Ilia State University, Tbilisi 0162, Georgia; ozgur.kisi@iliauni.edu.ge \\ * Correspondence: rawshan.ali@epu.edu.iq
}

Received: 22 January 2020; Accepted: 25 March 2020; Published: 26 March 2020

\begin{abstract}
This study aimed to assess the interrelationship among extreme natural events and their impacts on environments and humans through a systematic and quantitative review based on the up-to-date scientific literature. Namely, the main goal was to add additional knowledge to the existing evidence of the impacts related to floods, droughts, and landslides on humans and the environment in China; this in order to identify knowledge gaps in research and practice to aid in improving the adaptation and mitigation measures against extreme natural events in China. In this study, 110 documents were analyzed in the evaluation of several impacts triggered by extreme events. Records were obtained from Scopus and Web of Science and examined with a text mining instrument to assess the pattern of publications over the years; the problems linked to extreme weather events were investigated, and the study gaps were discussed. This paper extends work by systematically reviewing recent evidence related to floods, droughts, and landslides in China. We listed the critical studies that focused on the impact of extreme events on both humans and the environment described in current reviews. The findings revealed that goods safety, social safety, and financial losses are of significant concern to the scientific community due to extreme natural events, which from our analysis resulted in being more frequent and intense. It is still underdeveloped to implement distant sensing and imaging methods to monitor and detect the impact of severe weather occurrences. There are still significant study gaps in the fields of the effects of extreme weather events. The analysis result shows that extreme events are increased during the time, so more in-depth investigation and efforts on adaptation, mitigation measures, and strategical governance plans are desperately required.
\end{abstract}

Keywords: flood; drought; landslide; environment; vulnerability

\section{Introduction}

The Intergovernmental Panel on Climate Change (IPCC) depicts an Extreme Weather Event [1] as unusual or less than the 10th or 90th percentile of an estimated likelihood density function [2]. The increasing frequency of extreme weather events (EWE) associated with climate change $[3,4]$ is a severe threat to agriculture and living beings. The long-lasting socioeconomic costs of heatwaves, floods, wildfires, hailstorms, and other EWE pose significant threats to farmers and communities, especially considering future predictions of climate change (CC) intensity, frequency, and spatiotemporal scope $[3,5,6]$. Weather disasters in China are causing billions of Chinese Yuan of damage, and significant loss of life [7]. Every year, in various regions across China, droughts, floods, landslides, or other weather disasters caused death, destruction, and significant agricultural losses [7-14]. Over the past several 
decades, extreme weather events have become increasingly frequent and severe. Extreme weather events can have severe harmful effects on crop yield and, therefore, the production of agricultural products $[3,5,6]$. During critical growth phases, most crops are sensitive to the direct effects of high temperature, decreased precipitation, flooding, and premature freezing. Through influences on soil processes, nutrient dynamics, and pest organisms, other effects on crops are indirect $[15,16]$.

The latest climate scenarios are characterized by a rise in extreme and uncertain occurrences [5]. In the ten years leading up to 2011, flooding was the most prevalent form of catastrophes worldwide, liable for nearly half of natural disaster victims and approximately US\$ 185 billion in financial losses. Floods are anticipated to increase in intensity and frequency owing to rising sea levels and the frequency of extreme precipitation events [2,17].

Increasing urbanization also means that more individuals are subjected to flooding incidents [18]. Although hydraulic models facilitate flood prediction [19-21] and help water managers to develop adaptation plans for the most vulnerable zones; still, China has dramatically experienced heavy losses over time from floods that covered a large area of land and caused substantial financial losses. In several cases, appropriate design of protection measures, such as dikes, may result in catastrophic floods [22]. Floods threaten around 0.10 of China's land and 0.70 of both industrial sectors and agriculture gross production value [7]. In the 1950s, the yearly flood-affected farmland region was, on average, 10.07 million $\mathrm{km}^{2}$. By the 1990s, the annual flood-affected agricultural area had grown to 15.81 million $\mathrm{km}^{2}$, and the non-farm areas not characterized as experiencing "floods" but as experiencing "disasters" had 9.01 million $\mathrm{km}^{2}$ [10,23-25]. Since the beginning of the 21st century, the yearly agricultural region impacted by floods and disasters has substantially dropped to about 10.73 million $\mathrm{km}^{2}[5,7,26,27]$. Because of efficient flood disaster prevention programs, the number of casualties was also reduced considerably from an average yearly toll of roughly 5200 fatalities in the 1960-2000 era to approximately 2000 in the initial ten years of the 21st century [25]. Figure 1 shows the most vulnerable regions in China, and the pictures show some consequences of floods in those regions.



Figure 1. The central panel shows the flood hazard index over China (after [25]). (a) Submerged neighborhood in Jiangxi province (credits: REUTERS); (b) high water level rise in Changsha, Hunan province (credits: Xinhua); and (c) Dajing city, Zhejiang province under floods, August 2019 (credits: VCG).

Droughts can have significant effects on water and heat's regional or even worldwide spatial-temporal patterns [28-31]. Frequent severe droughts dramatically diminish water supplies and have a substantial impact on global ecosystems and socio-economic growth [4,15,32-37]. 
China is included within the monsoon zone with a varied and complex setting and terrain. Global climate change has influenced China's temporal and spatial water and heat dissemination, leading to variation in biogeochemistry cycles. Climate change has altered the seasonal variation in atmospheric circulation-controlled precipitation [38,39]. Climate change has increasingly affected dryness, as well as contributes to the extreme rainfall shortage, more and more, which has become more severe due to anthropogenic pressures [40,41]. For example, North China's droughts in 2009 affected 157 million acres of farmland, and the extreme dryness in Southwest China between 2009 and 2010 reduced bread-basket production to 120 million acres. Droughts each year have affected about one-sixth of China's cultivated land, causing severe loss of grain. The drought-induced crop output decline is estimated to be around 1500-2500 million tons every year, representing approximately 4-8\% of grain production and over 55\% of total natural catastrophe losses in China.

Climate change has increasingly affected dryness, the extreme shortage of rainfall. For instance, the droughts in North China in 2009 caused 157 million acres of farmland to be affected, and from 2009 to 2010, the severe droughts in Southwest China reduced the production to 120 million acres [2] Droughts have affected about one-sixth of China's cultivated land over the last ten years and have caused severe grain losses. The drought-induced crop yield is estimated at 1500-2500 million tons per year, approximately $4-8 \%$ of grain production and more than $55 \%$ of overall natural disaster losses in China [42]. Researching the spatial-temporal variation of drought in China for sustainable development, especially agriculture and food security, is, therefore, of great importance [43].

Spatial variability in the flood hazard index in China is presented in Figure 1. Learning from the spatial trend showing the 1-in-100-year AMDP (annual maximum daily precipitation), it was found that the region with the highest flood threat consisted of the eastern coastal provinces and municipalities of Sichuan and Chongqing and the areas along the Yangtze River's middle reaches [25]. Therefore, researching the spatial-temporal variability of drought in China for sustainable growth, especially in food and agriculture safety, is of great importance [44].

Figure 2 shows the most vulnerable regions in China, and the pictures show some consequences of droughts in those specific regions. It also indicates the discreet severe drought in some parts of southern China, while the northwest deserts are neither in severe drought nor mild drought, which does not fit with the fact that the drought in China has become more and more severe from the southeast to the northwest [44].

Landslides are one of the most damaging geological disasters having the characteristics of a fast velocity, as well as a lengthy runout distance and impact on the terrain [45]. Heavy rainfall, earthquake, and engineering activity often trigger catastrophic landslide events. Based on the sliding body's spatial features and trajectory, the entire landslide motion process is primarily split into three phases: the beginning stage at the source region of the slide, the propagating phase, and the deposition phase [46]. Furthermore, during the landslide motion, there is entrainment, base liquefaction, and air cushioning. Risk assessment is often required to decrease the loss of landslide hazard [45]. The analysis of landslide runout is an extremely compelling strategy for assessing a landslide hazard. The maximum running distance, the velocity of propagation, and the deposit thickness form the basis for designing measures of remedial engineering, and were, for example, obtained through an analysis of the runout of the Zhengjiamo landslide on 12 August 2010, which took place in the residential area of Taijing Town, Tianshui City, Province of Gansu, northwest China (Figure 3). 


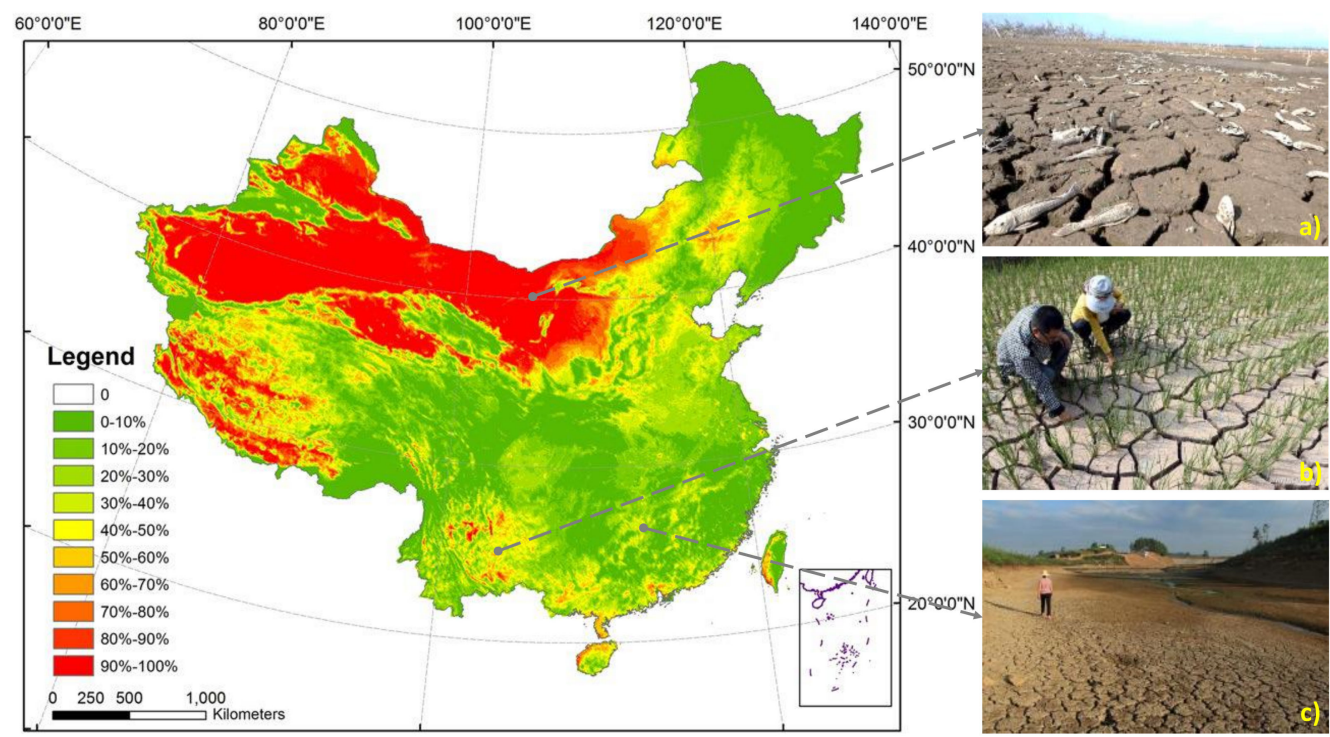

Figure 2. The central panel shows spatial distribution of drought frequency in China (after [44]. (a) Massive dead fish in a dried lake located in inner Mongolia (credits: http://earth-chronicles.com); (b) rice cultivated land, lack of soil moister and deep cracks in Xinqiao Township, southwest China's Yunnan Province, July 8, 2015 (credits: Xinhua/Yang Zongyou); and (c) Former Shima reservoir at Shima Village of Shaoyang County, central China's Hunan Province, July 27, 2013, completely dried-up (credits: Xinhua/Yang Zongyou).
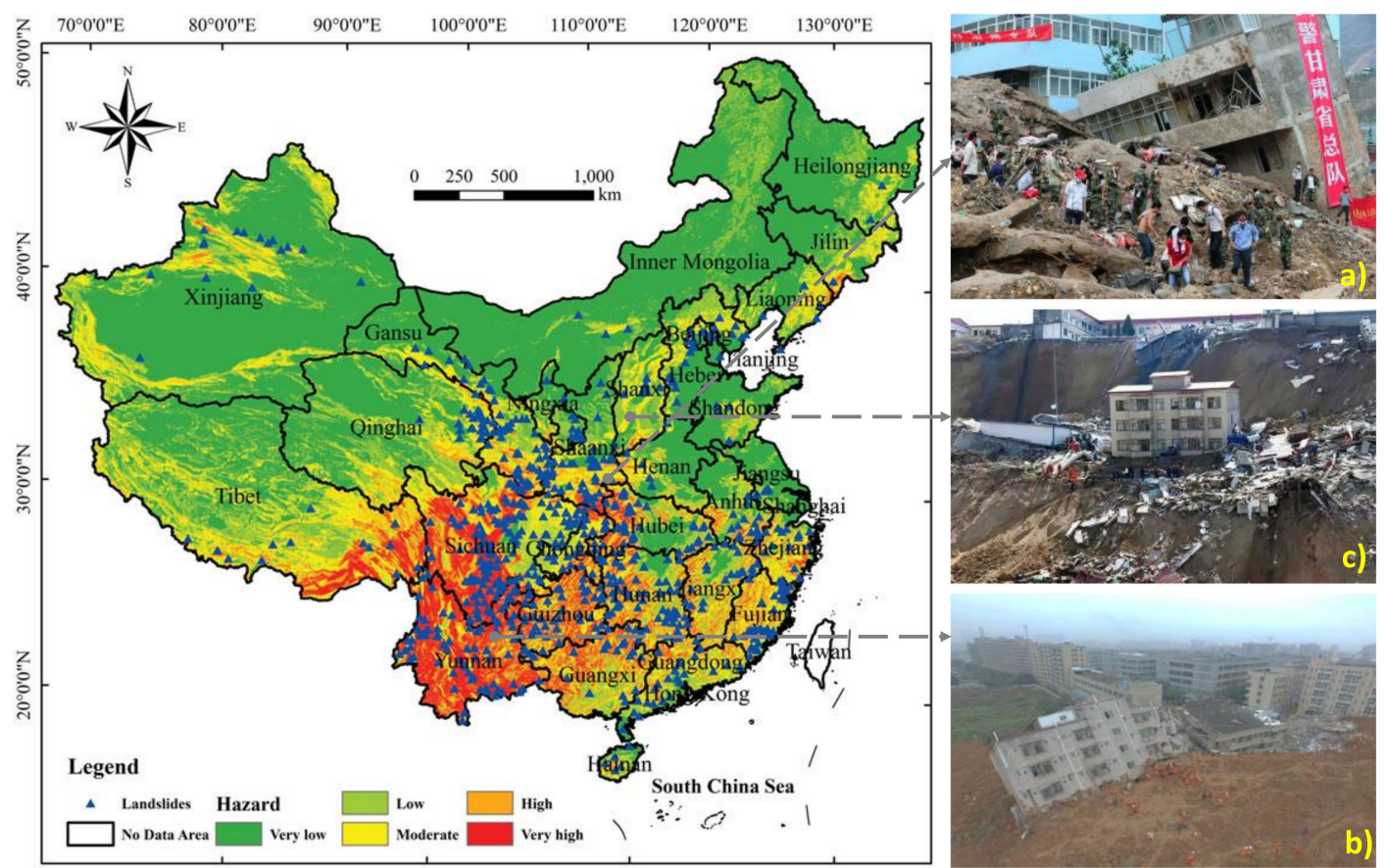

Figure 3. The central panel shows hazard landslides map over China. (a) Massive landslide in Zhouqu on August 12, 2010, in northwest China's Gansu province destroyed several houses and many people died (credits: FREDERIC J. BROWN/AFP/Getty Images); (b) residential buildings collapsed during a landslide in Xiangning county in Shanxi province (credits: Handout); and (c) buildings collapse during a landslide in Shenzhen, Guangdong province (credits: REUTERS).

Analysis of landslide runout includes two essential points: mapping past landslides and forecast of potential landslides [46]. Runout examination, such as barricades and berms, can be utilized for designing measures of remedial engineering [47]. The slope failure was activated by an earthquake in 
734 cases, as per local records and past studies. [48]. The landslide slid with a first sliding direction of $165^{\circ}-170^{\circ}$ along with the bedrock layer. The soil conditions of the sliding body were investigated by analyzing and interpreting five exploratory boreholes (Figure 3) $[49,50]$. The slipped area from the boreholes is around $2-3 \mathrm{~mm}$ thick. The landslide's sliding surface is a weak interlayer, consisting predominantly of mudstone blended with a soft interlayer. Figure 3 shows the most vulnerable regions in China, and pictures show some consequences of landslides in those specific regions [51]. Many studies have focused on the extreme climate and its change in China and surrounding areas over the past decade, and here we provide a review of this topic The subjects covered extreme events, flooding, drought, and landslides $[11,13,25,35,44,46,47,50,52-59]$. We discussed observational characteristics based on meteorological readings and atmospheric reanalysis, and assess the interrelationship among extreme natural events and their impacts on environments and humans through a systematic and quantitative-based review of the up-to-date scientific literature. Namely, the main goal was to add to the existing evidence of the impacts of floods, droughts, and landslides on humans and the environment in China. The paper is composed as follows: Section 2, methodologies; Section 3, primary outcomes and discussion; and, finally, the final remarks and outlook on future research are presented in Section 4.

\section{Materials and Methods}

A literature search was conducted using Scopus and Web of Science databases. The search was limited to papers published in English between 2000 and 2020. Moreover, keywords of extreme occurrences in China, such as flood, drought, and landslide, restricted these searches. The original search produced references for which abstracts were examined to exclude studies that did not fulfill the inclusion criteria, defined as flood events, drought events, and landslides throughout China. The authors then evaluated the full texts of the remaining papers critically. The original search for the three incidents is shown in Figure 4: flood, $\mathrm{n}=23797$; drought, $\mathrm{n}=14178$; and landslide, $\mathrm{n}=3865$-after removing duplicates and articles not linked to the three occurrences. The study's objective is to add evidence of flood, droughts, and landslide impacts in China on humans and the environment. It happened in China; therefore, it is crucial to find gaps in the knowledge in research and practice to improve events.

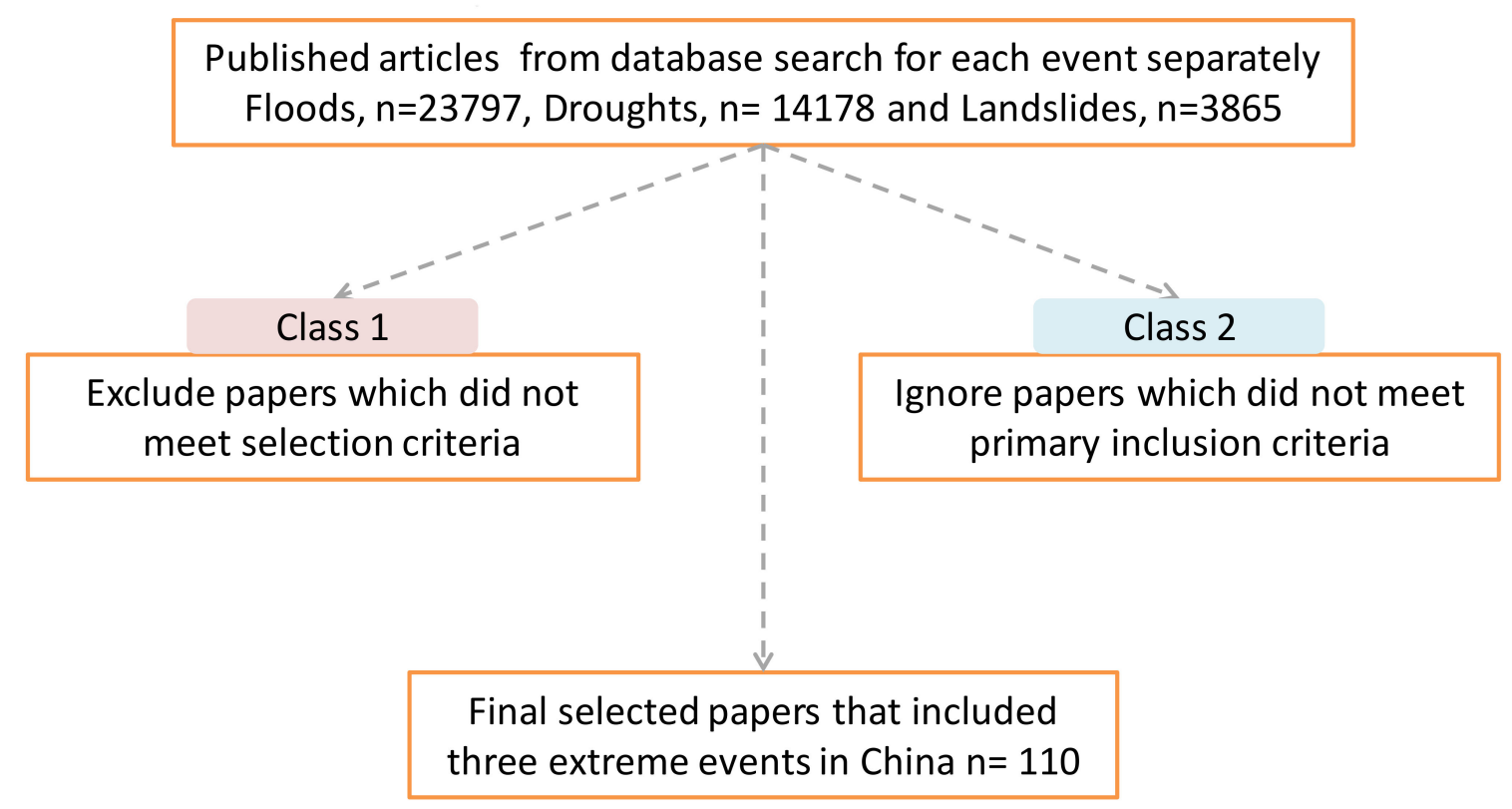

Figure 4. Flow chart of the article selection process. " $n$ " stands for the number of publications.

The purpose of the Class 1 review was to provide a general overview of the state-of-the-art research on extreme weather events, analyzing the pattern in the number of documents released 
between 2000 and 2020. Then the terms included in the dataset were grouped into abstract clusters to document the scientific community's main topics related to EWE. The established clusters were flood, drought, landslide, people, and climate. For each group, a word frequency analysis was carried out to identify the research hotspots and tendencies. The conceptual classification model is reported in Figure 4. In addition to the abovementioned empirical studies, the Class 2 dataset was developed through an in-depth analysis to provide a complete overview of the state-of-the-art in adaptation and mitigation of extreme weather events. A frequency research was carried out, contributing writers and sites within the classes of publications.

The terms in the title, keywords, and abstract were analyzed to identify potential interrelationships between topics and interconnections between extreme weather events and mitigation and adaptation. The extraction of the data set was based on a two-stage review. The first stage was aimed at carrying out a general discussion of the state-of-the-art of research on the human and environmental impact of extreme weather events. This goal was accomplished by the collection of records relating to EWE in the social and environmental subject area (Class 1). Stage two allowed the quest to be refined, combining extreme weather events with adaptation and mitigation (Class 2). Table 1 shows the scripts used to extract the words submitted for text mining.

Table 1. The scripts used to extract.

\begin{tabular}{cc}
\hline Class & Script of Extraction \\
\hline $\begin{array}{cc}\text { 1. Extreme Weather Events (subject } \\
\text { environment and human) }\end{array}$ & (TITLE-ABS ${ }^{*}$-KEY (extreme AND weather AND event in China)) \\
2. Extreme Weather Events & AND (LIMIT-TO (SUBJAREA, "Environment and Human")) \\
(Mitigation and Adaptations) & (TITLE-ABS-KEY (Adaptation and Mitigation)) \\
\hline & ${ }^{*}$ ABS-Abstract; KEY-Keywords.
\end{tabular}

\section{Results and Discussions}

After evaluating the full texts, the number and year of publication of those that remained are shown in Figure 5. This article expands previous [18] systematic reviews regarding the latest information relating to flooding, drought, and landslide events; 91 main studies in current reviews, and some new categories were considered.



Figure 5. The relationship between year and number of papers for three events. 
Figure 6 shows the relationship between the year and the number of events. As seen from the figure, the extreme events increased in time, so more studies on mitigation strategies and governance schemes are desperately required. This paper extends work by systematically reviewing recent evidence related to floods, droughts, and landslides in China. We listed below, in Tables 2-4; the key studies that focused on the types of human and environmental events described in the current reviews.

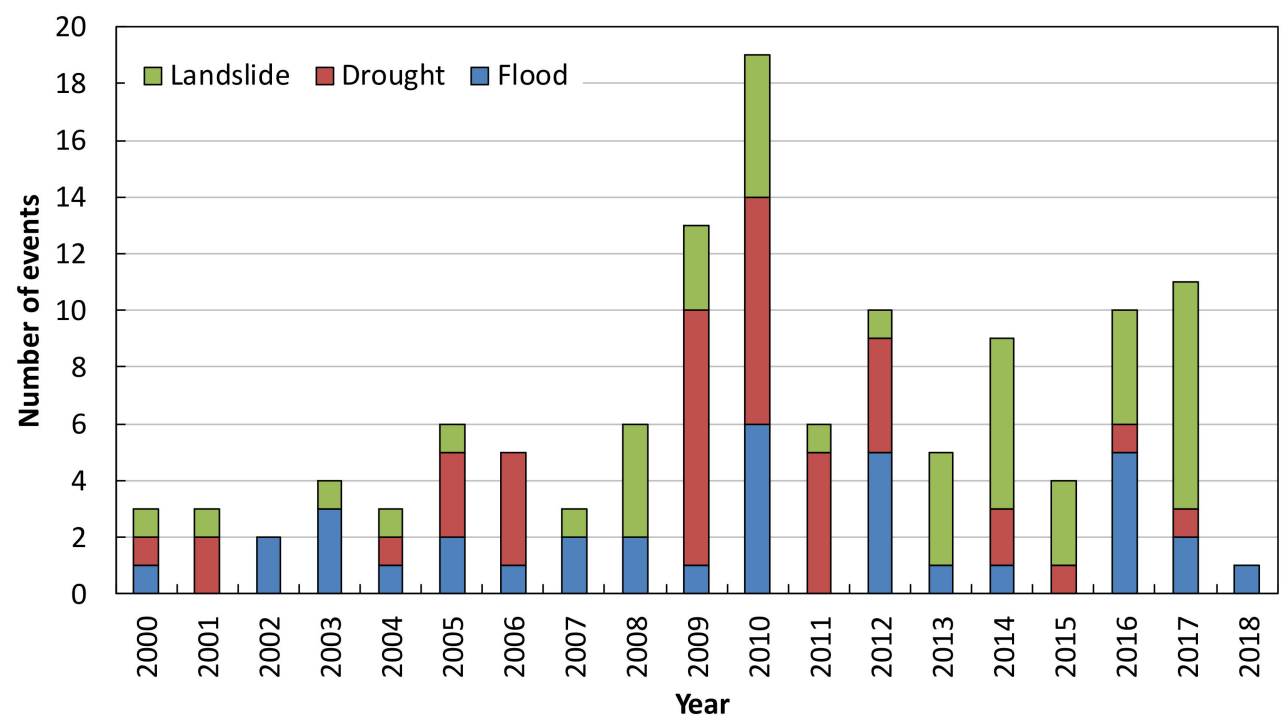

Figure 6. The relationship between year and number of events.

The latter included both human and environmental effects. We discovered that while most short-term effects are well documented, there is a need for a more robust understanding of longer-term impacts. The full texts of all remaining papers were critically evaluated and included in Table 2 for review.

\subsection{Droughts}

Droughts can have significant impacts on the national or even worldwide spatial-temporal structure of water and heat $[43,44,60]$. Frequent severe droughts severely decrease the availability of water and have a notable effect on the ecosystem and socio-economic growth of China [7,43,60-63]. China has the largest monsoon climate area in East Asia, where climate and landscape are diverse and complicated. Global climate change has altered China's temporal and spatial allocation of water and heat assets, leading to modifications in biogeochemical cycles that have altered the seasonal precipitation variability regulated by atmospheric circulation [64]. Climate change has increasingly influenced dryness, through a severe lack of rainfall [65]. Table 2 shows the characteristics of the critical studies of droughts. 
Table 2. Characteristics of key studies for drought events.

\begin{tabular}{|c|c|c|c|c|c|c|}
\hline \multirow{2}{*}{ Location } & \multirow{2}{*}{ Events } & \multirow{2}{*}{ Cause } & \multicolumn{2}{|c|}{ Consequence } & \multirow{2}{*}{$\begin{array}{c}\text { Mitigation and } \\
\text { Adaptation Measure }\end{array}$} & \multirow{2}{*}{ Reference } \\
\hline & & & Environment & Human & & \\
\hline $\begin{array}{l}\text { Yunnan } \\
\text { Province }\end{array}$ & $\begin{array}{l}2009 \text { and } \\
2010\end{array}$ & $\begin{array}{l}\text { A reduction in precipitation } \\
\text { and abnormal high } \\
\text { temperature. }\end{array}$ & $\begin{array}{l}\text { Severe water shortages dried } \\
\text { up lakes, exposed desiccated } \\
\text { aquatic animals, and affected } \\
39.94 \text { million hectares of crops. }\end{array}$ & $\begin{array}{l}\text { Shortage of drinking water } 9.65 \\
\text { million residents Almost } 135 \\
\text { million people dead, } 0.69 \\
\text { million USD indirect economic } \\
\text { loss in agriculture, and } 97 \\
\text { million livestock dead. }\end{array}$ & $\begin{array}{l}\text { Long-term adaptation } \\
\text { techniques, for example, } \\
\text { awareness-raising, capacity } \\
\text { building, watershed } \\
\text { management, and conservation } \\
\text { of resources, need to be } \\
\text { reinforced at the local level. }\end{array}$ & {$[34,60,66,67]$} \\
\hline $\begin{array}{l}\text { Heilongjiang } \\
\text { province }\end{array}$ & 2010 & $\begin{array}{l}\text { Natural characteristic indicator } \\
\text { of precipitation, and the } \\
\text { human activity characteristic } \\
\text { index including effective } \\
\text { irrigation area, sown area. }\end{array}$ & $\begin{array}{l}\text { Drought affected grain } \\
\text { product. }\end{array}$ & They were not reported. & $\begin{array}{l}\text { The significant extension of the } \\
\text { sown region and the reduced } \\
\text { irrigation water together in the } \\
\text { active irrigation region } \\
\text { exacerbated drought growth. }\end{array}$ & [55] \\
\hline $\begin{array}{l}\text { Heilongjiang, } \\
\text { Jilin and } \\
\text { Liaoning } \\
\text { Province }\end{array}$ & 2001 & $\begin{array}{l}\text { Because of geographical } \\
\text { location and impacted by } \\
\text { climate disaster. }\end{array}$ & They were not reported. & $\begin{array}{l}\text { Approximately } 890 \text { million } \\
\text { yuan economic loss per year. }\end{array}$ & $\begin{array}{l}\text { The effect of drought on maize } \\
\text { yield accurately and building a } \\
\text { multi-hazard evaluation model } \\
\text { to evaluate meteorological } \\
\text { risks, and their impact on yield } \\
\text { is crucial for future research. }\end{array}$ & [43] \\
\hline $\begin{array}{l}\text { Shaanxi } \\
\text { Province }\end{array}$ & 2012 & $\begin{array}{l}\text { High rate and level of loss in } \\
\text { agricultural production. }\end{array}$ & Water shortage crop failure. & Locust plagues. & $\begin{array}{l}\text { Using the cross-base predictor } \\
\text { selection method, the XG Boost } \\
\text { model demonstrated the best } \\
\text { predictive capabilities. }\end{array}$ & [27] \\
\hline $\begin{array}{l}\text { Yangtze } \\
\text { River }\end{array}$ & $\begin{array}{l}2005 \text { and } \\
2011\end{array}$ & Severe climate conditions. & Damaged eco-environment. & Socio-economic consequences. & $\begin{array}{l}\text { Scaling down the GRACE } \\
\text { information to a finer-scaled } \\
\text { resolution dependent on a soil } \\
\text { surface model and after that, } \\
\text { using downscaled information } \\
\text { to explore the spatial variations } \\
\text { in the characterization of } \\
\text { hydrological drought. }\end{array}$ & {$[54,68,69]$,} \\
\hline $\begin{array}{l}\text { Mid-eastern } \\
\text { China }\end{array}$ & 2006 & $\begin{array}{l}\text { Uneven spatial distribution of } \\
\text { precipitation caused by the } \\
\text { East Asian monsoon climate. }\end{array}$ & $\begin{array}{l}\text { Affected crops, grassland, and } \\
\text { deciduous broadleaf forest. }\end{array}$ & & $\begin{array}{l}\text { The Integrated Surface } \\
\text { Drought Index (ISDI) was } \\
\text { established as a fresh } \\
\text { technique. }\end{array}$ & [63] \\
\hline
\end{tabular}


Table 2. Cont.

\begin{tabular}{|c|c|c|c|c|c|c|}
\hline \multirow{2}{*}{ Location } & \multirow{2}{*}{ Events } & \multirow{2}{*}{ Cause } & \multicolumn{2}{|c|}{ Consequence } & \multirow{2}{*}{$\begin{array}{c}\text { Mitigation and } \\
\text { Adaptation Measure }\end{array}$} & \multirow{2}{*}{ Reference } \\
\hline & & & Environment & Human & & \\
\hline $\begin{array}{l}\text { Southwest } \\
\text { China }\end{array}$ & $\begin{array}{l}2005,2006 \\
\text { and } 2012\end{array}$ & $\begin{array}{l}\text { Climate change } \\
\text { geomorphology and } \\
\text { mountainous topography } \\
\text { alteration. }\end{array}$ & $\begin{array}{l}\text { Caused the maize production } \\
\text { to decrease by } 4.7 \% \text {. }\end{array}$ & Lack of freshwater for people. & $\begin{array}{l}\text { Comprehensive analysis of } \\
\text { spatiotemporal variation from } \\
\text { a climatic perspective based on } \\
\text { multiple drought indices to } \\
\text { improve the accuracy of } \\
\text { recognized drought events. }\end{array}$ & {$[35,70]$} \\
\hline China & $\begin{array}{l}2006,2009 \text { to } \\
2010 \text {, and } \\
2017\end{array}$ & Monsoon climate change. & $\begin{array}{c}\text { Affected agriculture, water } \\
\text { availability, and ecosystems. } \\
\text { Grain loss of } 16.26 \text { billion } \\
\text { kilograms. }\end{array}$ & $\begin{array}{l}\text { Impacts on the economy and } \\
\text { society. }\end{array}$ & $\begin{array}{l}\text { The Palmer Drought Severity } \\
\text { Index high-accuracy } \\
\text { self-calibration to explore the } \\
\text { drought variation in China. }\end{array}$ & [71] \\
\hline $\begin{array}{l}\text { North China } \\
\text { plane }\end{array}$ & $\begin{array}{l}2012 \text { and } \\
2009\end{array}$ & Climate change. & $\begin{array}{l}\text { Crop yield loss of } 157 \text { million } \\
\text { acres of farmland being } \\
\text { affected. }\end{array}$ & & $\begin{array}{l}\text { Drought indices were used to } \\
\text { develop the North China Plain } \\
\text { (NCP) aggregate drought index } \\
\text { (ADI) to evaluate the impact of } \\
\text { drought on crop yield. }\end{array}$ & {$[44,62]$} \\
\hline $\begin{array}{l}\text { Songnen } \\
\text { Plain }\end{array}$ & $\begin{array}{l}2000 \text { and } \\
2012\end{array}$ & $\begin{array}{c}\text { Agricultural drought disaster } \\
\text { type. }\end{array}$ & Crops. & Lack of food for the people. & $\begin{array}{l}\text { Verify and evaluate the } \\
\text { applicability of this recently } \\
\text { proposed soil water deficit } \\
\text { index (MSWDI) to monitor } \\
\text { agricultural drought to } \\
\text { advance the management of } \\
\text { agricultural water. }\end{array}$ & [72] \\
\hline $\begin{array}{l}\text { Tarim River } \\
\text { Basin }\end{array}$ & 2009 & Climate change. & $\begin{array}{c}\text { The severe loss of oasis } \\
\text { agriculture. }\end{array}$ & & $\begin{array}{l}\text { Modelling the connection } \\
\text { between ecological water } \\
\text { supply and irrigation water } \\
\text { supply through the } \\
\text { Community Land } \\
\text { Model-Distributed } \\
\text { Time-Variant Gain Model } \\
\text { (CLM-DTVGM) and a copula } \\
\text { feature. }\end{array}$ & [12] \\
\hline
\end{tabular}


Table 2. Cont.

\begin{tabular}{|c|c|c|c|c|c|c|}
\hline \multirow{2}{*}{ Location } & \multirow{2}{*}{ Events } & \multirow{2}{*}{ Cause } & \multicolumn{2}{|c|}{ Consequence } & \multirow{2}{*}{$\begin{array}{c}\text { Mitigation and } \\
\text { Adaptation Measure }\end{array}$} & \multirow{2}{*}{ Reference } \\
\hline & & & Environment & Human & & \\
\hline $\begin{array}{l}\text { Southwestern } \\
\text { China }\end{array}$ & $\begin{array}{l}2009 \text { and } \\
2011\end{array}$ & Climate change. & $\begin{array}{l}\text { Declined vegetation } \\
\text { productivity, increased tree } \\
\text { impermanence. The } 2011 \\
\text { summer drought dried up } \\
\text { more than } 1500 \text { small } \\
\text { reservoirs affecting about } 2.5 \\
\text { million ha farmland. }\end{array}$ & $\begin{array}{l}\text { Drinking water shortages for } \\
9.65 \text { million people, } 21 \text { million } \\
\text { people lacked drinking water, } \\
\text { and economic losses reached } \\
\text { almost } 30 \text { billion USD. }\end{array}$ & $\begin{array}{l}\text { The resistance of vegetation } \\
\text { growth to drought must be } \\
\text { recognized by integrating field } \\
\text { measurements and satellite } \\
\text { observations. }\end{array}$ & {$[73,74]$} \\
\hline $\begin{array}{l}\text { Shaanxi, } \\
\text { Qinghai, } \\
\text { and } \\
\text { Guangdong }\end{array}$ & $\begin{array}{l}2009 \text { and } \\
2011\end{array}$ & Climate change. & Crop yields. & They were not reported. & $\begin{array}{l}\text { Increasing education and social } \\
\text { capital improve farmers' } \\
\text { capacity to adapt and the } \\
\text { policy of strengthening } \\
\text { community assets to adapt to } \\
\text { extreme weather events. }\end{array}$ & [7] \\
\hline $\begin{array}{l}\text { Northeast } \\
\text { China }\end{array}$ & $\begin{array}{l}2001 \text { and } \\
2014\end{array}$ & $\begin{array}{l}\text { High fluctuation in monthly } \\
\text { rainfall. }\end{array}$ & $\begin{array}{l}\text { Northeast China was attacked } \\
\text { by drought in 2001, and the } \\
\text { drought area reached } 3.75 \\
\text { million hectares in the } \\
\text { Heilongjiang region, and } 2.7 \\
\text { million hectares in Jilin } \\
\text { Province of which the area } \\
\text { attacked severely by drought } \\
\text { was } 2.04 \text { million hectares. }\end{array}$ & $\begin{array}{l}\text { It was causing a significant } \\
\text { economic loss. }\end{array}$ & $\begin{array}{l}\text { Three indices are the } \\
\text { Standardized Monthly } \\
\text { Precipitation Anomaly } \\
\text { Percentage (NPA), the } \\
\text { Vegetation Health Index (VHI), } \\
\text { and the Normalized Vegetation } \\
\text { Supply Water Index (NVSWI.) } \\
\text { Three broad indices use precise } \\
\text { and efficient tracking of } \\
\text { drought is very important for } \\
\text { ensuring grain production. }\end{array}$ & [65] \\
\hline $\begin{array}{l}\text { Pearl River } \\
\text { basin }\end{array}$ & 2016 & Precipitation anomalies. & They were not reported. & They were not reported. & $\begin{array}{l}\text { The response of extreme } \\
\text { hydro-climates to El Niño can } \\
\text { give useful data to enhance } \\
\text { flood forecasting and drought } \\
\text { in China. }\end{array}$ & [52] \\
\hline
\end{tabular}


Table 2. Cont

\begin{tabular}{|c|c|c|c|c|c|c|}
\hline \multirow{2}{*}{ Location } & \multirow{2}{*}{ Events } & \multirow{2}{*}{ Cause } & \multicolumn{2}{|c|}{ Consequence } & \multirow{2}{*}{$\begin{array}{c}\text { Mitigation and } \\
\text { Adaptation Measure }\end{array}$} & \multirow{2}{*}{ Reference } \\
\hline & & & Environment & Human & & \\
\hline $\begin{array}{l}\text { Weihe River } \\
\text { Basin, } \\
\text { Gansu } \\
\text { Province }\end{array}$ & 2004 & Climate changes. & They were not reported. & They were not reported. & $\begin{array}{l}\text { Temperature impacts on } \\
\text { hydrological droughts cannot } \\
\text { be overlooked and have } \\
\text { indirect effects (rainfall } \\
\text { patterns) and direct } \\
\text { (evaporation and runoff } \\
\text { generation). }\end{array}$ & [64] \\
\hline $\begin{array}{l}\text { Southeast } \\
\text { China }\end{array}$ & $\begin{array}{l}2014 \text { and } \\
2015\end{array}$ & Climate change. & They were not reported. & They were not reported. & $\begin{array}{l}\text { The asymmetric response to } \\
\text { drought between autotrophic } \\
\text { soil respiration (Ra) and } \\
\text { heterotrophic soil respiration } \\
\text { (Rh) should be taken into } \\
\text { consideration when predicting } \\
\text { ecosystem Creation to future } \\
\text { drought occurrences. }\end{array}$ & [75] \\
\hline $\begin{array}{l}\text { Poyang lake- } \\
\text { catchment-river } \\
\text { system }\end{array}$ & 2011 & Significantly low precipitation. & They were not reported. & They were not reported. & $\begin{array}{c}\text { Adaptation strategy to mitigate } \\
\text { the worsening condition of the } \\
\text { Poyang lake-catchment-river } \\
\text { scheme should be created as a } \\
\text { matter of urgency. }\end{array}$ & [68] \\
\hline
\end{tabular}




\subsection{Floods}

Flood occurrences are the most frequent and damaging natural disasters, accounting for nearly half of all the natural disasters over the previous decade $[10,25,76,77]$. Due to severe precipitation occurrences and rising sea levels, flood frequency and intensity are expected to increase climate change situations [2,53]. China is currently one of the most flood-prone countries in the world and expected to experience considerably more changes than the global average in its climate this century [53]. Floods can trigger significant health losses, including deaths, accidents, mental health issues, communicable diseases, vector-borne illnesses, and waterborne diseases [18]. Table 3 shows the characteristics of the key studies for floods. 
Table 3. Characteristics of key studies for flood events.

\begin{tabular}{|c|c|c|c|c|c|c|}
\hline \multirow{2}{*}{ Location } & \multirow{2}{*}{ Events } & \multirow{2}{*}{ Cause } & \multicolumn{2}{|c|}{ Consequence } & \multirow{2}{*}{ Mitigation and Adaptation Measure } & \multirow{2}{*}{ Reference } \\
\hline & & & Environment & Human & & \\
\hline $\begin{array}{l}\text { Liaoning } \\
\text { Province }\end{array}$ & 2012 & Heavy rain. & Not reported. & 36 deaths. & $\begin{array}{l}\text { Structural measures, for example, the } \\
\text { construction of reservoirs for flood } \\
\text { control and the regular maintenance of } \\
\text { riverbeds and banks, are regarded as } \\
\text { critical. Equally essential are } \\
\text { non-structural measures, including } \\
\text { emergency planning. }\end{array}$ & [53] \\
\hline $\begin{array}{l}\text { Huaihe } \\
\text { River }\end{array}$ & $\begin{array}{l}2003 \text { and } \\
2007\end{array}$ & $\begin{array}{l}\text { Unique natural } \\
\text { future. }\end{array}$ & $\begin{array}{l}\text { Sixteen million hectares of } \\
\text { arable land flooded by floods; } \\
3.17 \text { million hectares were } \\
\text { cultivated land in the } \\
\text { Yangtze River basin. }\end{array}$ & $\begin{array}{l}\text { Cause migration and thus } \\
\text { resettlement issues and direct } \\
\text { economic loss. }\end{array}$ & $\begin{array}{l}\text { Building flood structures can cause risk } \\
\text { propagation, so we must correctly treat } \\
\text { risk propagation; various regions must } \\
\text { share flood risk plans and build } \\
\text { mechanisms for flood risk compensation } \\
\text { and flood insurance. }\end{array}$ & {$[24,77]$} \\
\hline $\begin{array}{l}\text { Anhui } \\
\text { Province, } \\
\text { Jiangsu, and } \\
\text { Guangxi }\end{array}$ & $\begin{array}{l}\text { 2004, 2005, } \\
\text { 2012, 2016, } \\
\text { and 2017 }\end{array}$ & Heavy rainfall. & $\begin{array}{l}\text { 1120-thousand-hectare crop } \\
\text { area was devastated. }\end{array}$ & $\begin{array}{l}12.8 \text { million people were } \\
34 \text { people killed; the direct } \\
\text { economic loss was assessed to } \\
\text { be } 8.25 \text { billion US dollars. }\end{array}$ & $\begin{array}{l}\text { It is recommended that local public } \\
\text { health organizations create intervention } \\
\text { programs to avoid and control the } \\
\text { danger of diarrhea when a significant } \\
\text { flood happens, particularly in the } \\
\text { regions close to water bodies and among } \\
\text { vulnerable communities. }\end{array}$ & {$[9,13,25,78-80]$} \\
\hline Wuhan & 2016 & Heavy rainstorm. & $\begin{array}{l}32,160 \text { ha of crops and } \\
\text { vegetables were destroyed. }\end{array}$ & $\begin{array}{c}\text { Fourteen people died, and one } \\
\text { person went missing. A total of } \\
757000 \text { people was resettled, } \\
\text { and } 5848 \text { houses were warped. } \\
\text { Economic losses were assessed } \\
\text { to be higher than } 22.65 \text { billion } \\
\text { RMB ( } 3.3 \text { billion USD). }\end{array}$ & $\begin{array}{l}\text { It is suggested that the Sponge City } \\
\text { (SPC) idea be implemented to replace } \\
\text { traditional green infrastructure. }\end{array}$ & {$[23,81]$} \\
\hline $\begin{array}{l}\text { Fujian } \\
\text { Province }\end{array}$ & 2013 & $\begin{array}{l}\text { Typhoon Fitow, } \\
\text { massive rainfall } \\
\text { reservoirs, and } \\
\text { drainage systems } \\
\text { were already at a } \\
\text { high level. }\end{array}$ & & $\begin{array}{l}\text { It affected three million people } \\
\text { and cost over } 0.33 \text { billion US\$. }\end{array}$ & $\begin{array}{l}\text { Linking the flood model to real-time } \\
\text { predictions of rainfall and tide would } \\
\text { enable the computation of flood } \\
\text { probability in real-time and thus take } \\
\text { effective action to decrease flood effects. }\end{array}$ & [10] \\
\hline
\end{tabular}


Table 3. Cont

\begin{tabular}{|c|c|c|c|c|c|c|}
\hline \multirow{2}{*}{ Location } & \multirow{2}{*}{ Events } & \multirow{2}{*}{ Cause } & \multicolumn{2}{|c|}{ Consequence } & \multirow{2}{*}{ Mitigation and Adaptation Measure } & \multirow{2}{*}{ Reference } \\
\hline & & & Environment & Human & & \\
\hline Guangzhou & $\begin{array}{l}2010 \text { and } \\
2014\end{array}$ & $\begin{array}{c}\text { Extreme rainfall } \\
\text { event. }\end{array}$ & $\begin{array}{c}\text { Caused many streets to become } \\
\text { inundated. }\end{array}$ & $\begin{array}{l}\text { It was leading to severe } \\
\text { transport disorder. }\end{array}$ & $\begin{array}{l}\text { It is also suggested that urban flooding } \\
\text { records in areas with flood danger be } \\
\text { collected regularly so that more suitable } \\
\text { policies and interventions can be } \\
\text { established to mitigate urban flooding. }\end{array}$ & [23] \\
\hline $\begin{array}{l}\text { Xinjiang } \\
\text { Province }\end{array}$ & 2010 & & $\begin{array}{l}\text { Human damaged was very } \\
\text { severe, with some } 3200 \\
\text { fatalities nationwide and a } \\
\text { thousand missing. }\end{array}$ & $\begin{array}{l}\text { Seventy-nine fatalities and } 11.6 \\
\text { billion CN¥ (1.85 billion US\$, } \\
\text { in } 2012 \text { exchange rate) losses. }\end{array}$ & $\begin{array}{l}\text { China has embarked on an ambitious } \\
\text { and vigorous task of improving flood } \\
\text { preparedness through both structural } \\
\text { ("hard") and non-structural ("soft"), } \\
\text { measures, including flood retention and } \\
\text { urban water management to mitigate } \\
\text { flash and urban flood burdens. }\end{array}$ & {$[23,81]$} \\
\hline
\end{tabular}




\subsection{Landslides}

Landslides are a very complicated natural phenomenon that create a severe loss of lives and assets throughout China [8,11,49,50,58,82-87]. Over the years, many government agencies have sought alternatives to mitigate the catastrophic consequences of landfill slides by teaching individuals to understand the severe impacts of landfill slides better and by creating proper scheduling for mitigation and decision-making tools $[48,56,57]$. This procedure is generally performed by identifying and mapping of the regions susceptible to landslides. These maps are produced dependent on a landslide susceptibility evaluation, which is a relative distribution of landslide probabilities in a specified area dependent on local geo-environmental variables $[8,84,88]$. Through the background of the research of landslides activated by the earthquake, scientists endeavored to know the essentials of the landslide events, processes, and ranges triggered by the quake $[8,11,47-49,58]$. Researchers have sought to explore the spatial allocation models and control variables of these landslides. Table 4 shows the characteristics of the key studies for landslides. 
Table 4. Characteristics of critical studies for landslide events

\begin{tabular}{|c|c|c|c|c|c|c|}
\hline \multirow{2}{*}{ Location } & \multirow{2}{*}{ Events } & \multirow{2}{*}{ Cause } & \multicolumn{2}{|r|}{ Consequence } & \multirow{2}{*}{$\begin{array}{c}\text { Mitigation and } \\
\text { Adaptation Measure }\end{array}$} & \multirow{2}{*}{ Reference } \\
\hline & & & Environment & Human & & \\
\hline $\begin{array}{l}\text { Zhouqu } \\
\text { County }\end{array}$ & $\begin{array}{l}2010 \text { and } \\
2013\end{array}$ & $\begin{array}{l}\text { Slope deformation } \\
\text { Substantial erosion and } \\
\text { an active fault zone. }\end{array}$ & $\begin{array}{l}\text { They were not } \\
\text { reported. }\end{array}$ & They were not reported. & $\begin{array}{l}\text { Developing empirical models to } \\
\text { predict landslides events. The time } \\
\text { series of slope deformation has a } \\
\text { robust correlation with the } \\
\text { area's precipitation. }\end{array}$ & {$[51,89]$} \\
\hline China & $\begin{array}{l}\text { 2000, 2005, } \\
2014 \text {, and } \\
2015\end{array}$ & $\begin{array}{l}\text { Increase in extreme } \\
\text { precipitation in China } \\
\text { Earthquakes. }\end{array}$ & & $\begin{array}{l}\text { Property and Environmental } \\
\text { damage and over } 1700 \text { dead. }\end{array}$ & $\begin{array}{l}\text { The interactions between rainfall } \\
\text { and topography, soil lithology, } \\
\text { vegetation, and population density } \\
\text { are closer to the spatial distribution } \\
\text { of deadly landslides than each factor. }\end{array}$ & {$[56,57,90]$} \\
\hline $\begin{array}{l}\text { Sichuan } \\
\text { Province }\end{array}$ & $\begin{array}{l}\text { 2008, 2013, } \\
\text { and } 2017\end{array}$ & $\begin{array}{l}\text { Lushan earthquake, a } \\
\text { sharp shock happened. }\end{array}$ & $\begin{array}{l}\text { The avalanche also } \\
\text { blocked roads and the } \\
\text { Songpinggou River. }\end{array}$ & $\begin{array}{l}\text { Ten thousand nine hundred and } \\
\text { ninety-six total deaths, } \\
\text { approximately } 690 \text { fatalities per year } \\
120 \text { deaths from 2000-2015. }\end{array}$ & $\begin{array}{l}\text { Ground motion is the basic } \\
\text { triggering impact for these } \\
\text { landslides and is thus the central } \\
\text { control the distribution of landslides. }\end{array}$ & [11,49,58,59,87,88,91-94] \\
\hline $\begin{array}{l}\text { Three } \\
\text { Gorges } \\
\text { Reservoir } \\
\text { Area }\end{array}$ & $\begin{array}{l}2014 \text { and } \\
2003\end{array}$ & $\begin{array}{l}\text { Moreover, the reservoir } \\
\text { water level reached its } \\
\text { maximum level of } 175 \mathrm{~m}, \\
\text { and substantial } \\
\text { rainfall-induced landslide } \\
\text { deformation occurred. }\end{array}$ & $\begin{array}{l}\text { They were not } \\
\text { reported. }\end{array}$ & $\begin{array}{c}\text { Two hundred and seventeen } \\
\text { fatalities; } 13,484 \text { persons were } \\
\text { injured, and about 193,000 houses } \\
\text { were destroyed. It was estimated } \\
\text { that the total economic losses } \\
\text { exceeded } 50 \text { billion Yuan. Extensive } \\
\text { damage to housing settlements and } \\
\text { irrigation channels. Highways and } \\
\text { bridges were also blocked and } \\
\text { destroyed; several cities } \\
\text { were isolated. }\end{array}$ & $\begin{array}{l}\text { The effect of filling reservoir water } \\
\text { on landslide stability will shift from } \\
\text { favorable to worse, and the effect of } \\
\text { the water drawn from the reservoir } \\
\text { on the landslide stability will alter } \\
\text { from worse to better if the water } \\
\text { fluctuation rate of the reservoir is } \\
\text { less than or equal to the coefficient of } \\
\text { permeability, the effect, and trend of } \\
\text { the landslide development will be } \\
\text { more evident. }\end{array}$ & {$[95,96]$} \\
\hline $\begin{array}{l}\text { Jiangliu } \\
\text { Village on } \\
\text { the South } \\
\text { Jingyang } \\
\text { tableland }\end{array}$ & 2016 & $\begin{array}{l}\text { Soft foundation impact } \\
\text { liquefaction became the } \\
\text { primary reason that the } \\
\text { landslide occurred. }\end{array}$ & Affected farmland. & $\begin{array}{l}\text { Seriously threatens people's safety } \\
\text { and property }\end{array}$ & $\begin{array}{l}\text { Large pores within the slope and the } \\
\text { vertical joints were preferential } \\
\text { infiltration passages for irrigation } \\
\text { water, and landslides in the flow } \\
\text { stated that the ground layer in the } \\
\text { reduced portion of the slope before } \\
\text { the landslide was in a completely } \\
\text { saturated condition. }\end{array}$ & [83] \\
\hline
\end{tabular}


Table 4. Cont.

\begin{tabular}{|c|c|c|c|c|c|c|}
\hline \multirow{2}{*}{ Location } & \multirow{2}{*}{ Events } & \multirow{2}{*}{ Cause } & \multicolumn{2}{|r|}{ Consequence } & \multirow{2}{*}{$\begin{array}{c}\text { Mitigation and } \\
\text { Adaptation Measure }\end{array}$} & \multirow{2}{*}{ Reference } \\
\hline & & & Environment & Human & & \\
\hline $\begin{array}{l}\text { Guangchang } \\
\text { area Jiangxi } \\
\text { province }\end{array}$ & $\begin{array}{l}\text { Last ten } \\
\text { years }\end{array}$ & Heavy rainfall. & $\begin{array}{l}\text { They were not } \\
\text { reported. }\end{array}$ & $\begin{array}{l}\text { It has impacted } 1392 \text { people, } \\
\text { including some killed, made } \\
\text { homeless, among others. }\end{array}$ & $\begin{array}{l}\text { Consequently, the outcome shows } \\
\text { that the J48 Decision Tree (JDT) with } \\
\text { Rotation Forest is the best-optimized } \\
\text { model and can be regarded as a } \\
\text { successful technique for mapping } \\
\text { landslide susceptibility for greater } \\
\text { precision in comparable instances. }\end{array}$ & [97] \\
\hline Shenzhen & 2015 & Construction solid waste. & $\begin{array}{l}\text { Had catastrophic } \\
\text { consequences. }\end{array}$ & $\begin{array}{c}\text { Buried or pushed over } 33 \text { buildings } \\
\text { in its path, namely, } 24 \text { workshops, } \\
\text { three dormitory buildings, and six } \\
\text { residential buildings, and caused } 73 \\
\text { deaths and } 17 \text { injures. }\end{array}$ & $\begin{array}{l}\text { The reasonable agreement between } \\
\text { the damage observed and the } \\
\text { simulation presented by the } \\
\text { procedural analysis provides } \\
\text { evidence indicating the usefulness of } \\
\text { both the model of dilatancy used to } \\
\text { study the landslide movement and } \\
\text { the method of dynamic finite } \\
\text { element analysis implemented to the } \\
\text { exposed structure. }\end{array}$ & [84] \\
\hline $\begin{array}{l}\text { Wuyuan } \\
\text { area }\end{array}$ & 2014 & $\begin{array}{l}\text { Numerous } \\
\text { rainfall }\end{array}$ & Not reported. & $\begin{array}{l}\text { A total of } 2115 \text { people is affected. } \\
\text { The economic loss of } 4 \text { million USD; } \\
\text { destroyed homes and agriculture }\end{array}$ & $\begin{array}{l}\text { A decision support instrument could } \\
\text { use the results of this research to } \\
\text { implement infrastructure security } \\
\text { plans and risk reduction } \\
\text { initiatives effectively. }\end{array}$ & [97] \\
\hline Yunnan & $\begin{array}{l}2014 \text { and } \\
2003\end{array}$ & $\begin{array}{l}\text { Ludian earthquake } \\
\text { Seismogenic fault. } \\
\text { Shallow slope failures } \\
\text { and rock or soil slides }\end{array}$ & $\begin{array}{l}\text { It blocked the Niulan } \\
\text { river creating a } \\
\text { reservoir that had a } \\
\text { high likelihood of } \\
\text { landslide dam failure } \\
\text { and subsequent } \\
\text { downstream flood. }\end{array}$ & $\begin{array}{l}\text { Created an elevated risk to the } \\
\text { population, and effective emergency } \\
\text { mitigation measures were carried } \\
\text { out, the risk of dam break was } \\
\text { decreased significantly. }\end{array}$ & $\begin{array}{l}\text { The properties of the "best-fit" input } \\
\text { strength are equivalent, but not the } \\
\text { actual power of the displaced } \\
\text { material or the adjacent stable } \\
\text { base rock. }\end{array}$ & {$[8,98]$} \\
\hline
\end{tabular}


Table 4. Cont

\begin{tabular}{|c|c|c|c|c|c|c|}
\hline \multirow{2}{*}{ Location } & \multirow{2}{*}{ Events } & \multirow{2}{*}{ Cause } & \multicolumn{2}{|r|}{ Consequence } & \multirow{2}{*}{$\begin{array}{c}\text { Mitigation and } \\
\text { Adaptation Measure }\end{array}$} & \multirow{2}{*}{ Reference } \\
\hline & & & Environment & Human & & \\
\hline $\begin{array}{l}\text { Qinba } \\
\text { Mountains, } \\
\text { southern } \\
\text { Shaanxi } \\
\text { Province } \\
\text { western } \\
\text { China } \\
\end{array}$ & 2010 & $\begin{array}{l}\text { Geological factors and } \\
\text { precipitation. }\end{array}$ & Not reported. & 29 deaths & $\begin{array}{l}\text { 3D analyses utilizing 3DEC can well } \\
\text { represent the block kinematics of } \\
\text { instability; the impact of rainfall was } \\
\text { modeled on the numerical analysis } \\
\text { by decreasing the strengths of the } \\
\text { joints to defined values. Therefore, } \\
\text { 3D numerical results are still limited. }\end{array}$ & [82] \\
\hline $\begin{array}{l}\text { Yellow River } \\
\text { in China. }\end{array}$ & 2009 & $\begin{array}{l}\text { Revealing an acceleration } \\
\text { of deformation after the } \\
\text { impoundment of } \\
\text { the reservoir }\end{array}$ & Not reported. & They were not reported. & $\begin{array}{l}\text { Quantitative validation based on } \\
\text { ground-real-time information, track } \\
\text { landslides and invert slide depth } \\
\text { based on the 3D displacement field. }\end{array}$ & [99] \\
\hline $\begin{array}{l}\text { Nayong, } \\
\text { Guizhou, } \\
\text { China }\end{array}$ & $\begin{array}{l}2017 \text { and } \\
2010\end{array}$ & $\begin{array}{l}\text { Disastrous rock } \\
\text { avalanche occurred } \\
\text { heavy rainfall }\end{array}$ & $\begin{array}{l}\text { The landslide } \\
\text { involved the failure of } \\
\text { about } 985,000 \mathrm{~m}^{3} \text { of } \\
\text { sandstone from the } \\
\text { source area. The } \\
\text { displaced materials } \\
\text { traveled about } 1300 \mathrm{~m} \\
\text { with a descent of } \\
\text { about } 400 \mathrm{~m}, \text { covering } \\
\text { an area of } 129,000 \mathrm{~m}^{2} \\
\text { with the final volume } \\
1,840,000 \mathrm{~m}^{3}, \\
\text { approximately. }\end{array}$ & $\begin{array}{c}\text { Killed } 35 \text { people and destroyed } \\
23 \text { houses. }\end{array}$ & $\begin{array}{l}\text { Techniques combined the DAN3D } \\
\text { model with seismic signal and } \\
\text { captured video could give useful } \\
\text { rheological models and parameters } \\
\text { for predicting rock avalanche } \\
\text { comparable geological } \\
\text { characteristics to the } \\
\text { recorded events. }\end{array}$ & {$[14,50]$} \\
\hline $\begin{array}{l}\text { Yueqing of } \\
\text { Zhejiang } \\
\text { Province }\end{array}$ & 2004 & Typhoon & Not reported. & $\begin{array}{l}\text { Forty-two deaths, } 288 \text { collapse } \\
\text { houses, and direct economic loss of } \\
\text { 3,830,000 RMB. }\end{array}$ & $\begin{array}{l}\text { The findings of coarse resolution } \\
\text { information may also be acceptable } \\
\text { if information resolution is near to } \\
\text { the mean landslide magnitude. This } \\
\text { technique can also be adopted when } \\
\text { obtaining high-resolution } \\
\text { information is hard or very costly. }\end{array}$ & {$[100]$} \\
\hline
\end{tabular}


Table 4. Cont.

\begin{tabular}{|c|c|c|c|c|c|c|}
\hline \multirow{2}{*}{ Location } & \multirow{2}{*}{ Events } & \multirow{2}{*}{ Cause } & \multicolumn{2}{|r|}{ Consequence } & \multirow{2}{*}{$\begin{array}{c}\text { Mitigation and } \\
\text { Adaptation Measure }\end{array}$} & \multirow{2}{*}{ Reference } \\
\hline & & & Environment & Human & & \\
\hline $\begin{array}{l}\text { Loess } \\
\text { Plateau }\end{array}$ & 2001 & Environmental condition. & $\begin{array}{l}\text { Impacts on natural } \\
\text { vegetation. }\end{array}$ & They were not reported. & $\begin{array}{l}\text { Natural regeneration at the bottom } \\
\text { and center of the landslide was more } \\
\text { efficient, which disclosed that } \\
\text { modifications in topography could } \\
\text { influence revegetation. The seed } \\
\text { bank was regarded to be a significant } \\
\text { variable influencing natural } \\
\text { regeneration in the soil. }\end{array}$ & [85] \\
\hline $\begin{array}{l}\text { Shenzhen, } \\
\text { Guangdong, } \\
\text { south-eastern } \\
\text { China }\end{array}$ & 2015 & Slope failure & Not reported. & $\begin{array}{c}\text { Seventy-seven people were dead, } \\
\text { and } 33 \text { buildings that were directly } \\
\text { in the path of the landslide were } \\
\text { buried or damaged. }\end{array}$ & $\begin{array}{l}\text { Use the DAN3D technique to split } \\
\text { the route of movement, pick the } \\
\text { designs, and enter the parameters. }\end{array}$ & [101] \\
\hline Wenchuan & 2008 & $\begin{array}{l}\text { Earthquake area is } \\
\text { situated in seismic belt } \\
\text { and mountainous with } \\
\text { steep topography and } \\
\text { high erosion features }\end{array}$ & Not reported. & They were not reported. & $\begin{array}{l}\text { Human engineering operations may } \\
\text { boost the probability of landslides; } \\
\text { therefore, tourism-related human } \\
\text { engineering operations in landslide } \\
\text { susceptibility studies should not } \\
\text { be overlooked. }\end{array}$ & [48] \\
\hline Gansu & 2010 & Heavy rainfall & Not reported. & Killed 1287 people. & $\begin{array}{l}\text { The forecast capacity assessment } \\
\text { indicates that the two distinct maps } \\
\text { of susceptibility and the ultimate } \\
\text { embedded map of vulnerability to } \\
\text { landslides could also be used as } \\
\text { urgent reaction measures for } \\
\text { scheduling spatial development. }\end{array}$ & [47] \\
\hline Shenzhen & 2016 & $\begin{array}{l}\text { Deep geological and } \\
\text { geomorphological } \\
\text { fractures. }\end{array}$ & $\begin{array}{l}\text { They were not } \\
\text { reported. }\end{array}$ & Killed 77 people. & $\begin{array}{l}\text { Certain factors, such as flood } \\
\text { releases (which are state-regulated), } \\
\text { should be considered. However, the } \\
\text { variables that can lead to abrupt } \\
\text { declines in the reservoir level, which } \\
\text { causes landslide deformation to } \\
\text { remain unsure. }\end{array}$ & [86] \\
\hline
\end{tabular}


The migration-environment relation is not a recent trend. Environmental issues have also affected mobility in the community. Populations have always been prone to migrate in reaction to changes in the climate [102]. Urban migrants have emerged as a new status community within Chinese society since the mid-1980s [103]. Deng [104] found that natural disasters increase the small magnitude of migration.

Nevertheless, the migrant framework is substantially altered. Some rural residents are forced to migrate, but had there been no natural disasters, they would have remained in the countryside. Many are forced to relocate due to natural disasters and, relative to urban residents and other refugees, have the lowest level of income in the cities. The chances are that natural disaster-driven migration will adversely affect the civil protection. Pei [105] made the first attempt toward such a study, showing that the long-term impact of natural disasters on rural migration is short-term and almost instantaneous. Even though the agrarian society has a low buffering ability, the short-term effects of natural disasters may be somewhat eased. Given their limited forcefulness, however, population pressure will drive migration on a long-term scale [105]. The continuation—and enhancement—of opportunities to engage in conservation programs would be critical in reducing the environmental impacts of the combined effects of human interference and natural disasters, and not only in the area studies here, but also in many disaster-prone regions around the world [106].

\subsection{Extreme Weather}

The variations in extreme temperatures are most apparent among the extreme climate categories in China. China's average temperature is similar to the global mean temperature [6]. Extreme weather directly causes large portions of climate-related disasters $[5,6]$. Thus, climate change instability and long-term patterns have been important subjects of work on climate change. Understanding the observed changes in different types of extreme climate, improving the ability of climate models to reproduce the observed changes, and improving the techniques for projecting future changes in both dynamic and statistical approaches are equally important tasks for extreme climate studies $[5,6]$. First, in recording past changes in extreme climates in China, there are uncertainties. Changes in station sites and urbanization have had a significant impact on climate records. Homogeneity adjustments are therefore necessary to obtain the real trends for both mean climate and extreme climate [38], which is especially crucial for understanding extreme climate. Up to $20-30 \%$ of meteorological stations have been moved due to urbanization, mostly from near-city or urban locations to rural areas $[10,23,90]$. The length of the instrumental records is another concern. Because interdecadal variations are often combined with climate change signals, sufficiently long time series are required to differentiate climate change signals from interdecadal varieties $[107,108]$. Therefore, it will be useful for our studies to obtain meteorological data from Chinese historical documents (many of which contain meteorological information) over the past $3-5$ centuries. Tree rings and many other proxy data sets are also useful to extend the record and facilitate climate change research, interdecadal variation, and persistent extreme events. Although state-of-the-art climate models can replicate some observed characteristics of global average temperature and other quantities, their capacity to simulate extreme local climate is generally low except for extreme events. Extreme weather events attract a great deal of attention; climate change primarily damages human health by exacerbating existing disease burdens and adverse impacts on daily life among those with the weakest health protection systems and with the least adaptability. Therefore, most estimates suggest that poor and disenfranchised groups will bear the highest risk and, internationally, the highest-burden will fall on developing countries, especially poor children, who are today most affected by such climate-related diseases like malaria, undernutrition, and diarrhea.

Nevertheless, climate change's complex and global implications mean that higher-income communities can also be impacted by extreme events, evolving threats, and shifting impacts from more vulnerable populations. Climate extremes are especially challenging to research not only because of their rareness but also because of their background dependency, both in terms of the available (or selected) climate record and what the ecosystem and it is component species have encountered before [109]. As a consequence of this background dependency, ecological responses to climate changes 
can vary from little or no response to significant or "extreme" reactions (e.g., in terms of the distribution of possible environmental interventions, such as widespread mortality of an over-story tree species). As argued in this Special Issue's first paper [109], ecologists' significant challenges are deciding when an extreme climate occurs, when an ecological response is intense, and most critically, clearly attributing the extreme environment as the cause of the exaggerated ecological response. This latter case is characterized as an extreme climatic event (ECE), with the environmental and climatic combination of the extremity [109]. The value of the distinction between climate extremes and ECEs is evident in the paleoecological records of extreme ecological responses. These are standard features, such as state changes or regime shifts, but are not always attributable to extreme climate or even abrupt climate change. This distinction also can make it easier to determine how and why ecosystems can differ in their sensitivity to extreme climatic conditions, an issue addressed in more detail below. It follows from Smith's theoretical claims (2011) [109] that it is necessary to define both extreme climatic and extreme ecological responses to assess whether an ECE has taken place. The concept of extreme climate was relatively straightforward and was generally based on the statistical distribution of an environment variable for any system (Figure 7).

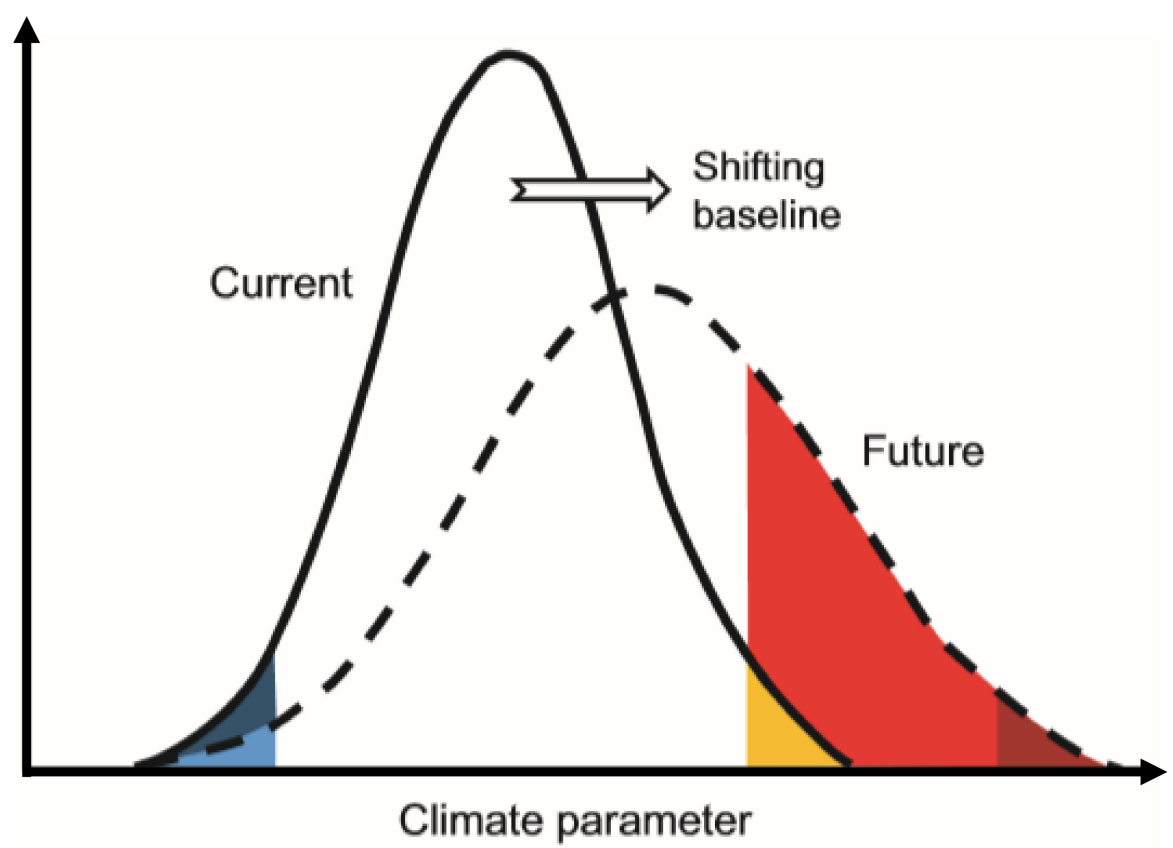

Figure 7. Qualitative representation of the climate extremes evolution modified from [6].

The prediction of a changing climate and/or instability is that in the future extreme climate will become more frequent and more severe [6]. This increase in frequency and intensity must be modeled on a fixed frame of reference or climatic context (e.g., historical climate record for a site) due to the quantitative nature of the description. For example, a change in mean temperatures to warmer conditions will result in a higher number of extremely high temperature based on the current statistical distribution (red shaded region, Figure 7), mainly if there is also increased variance around the mean. However, if the climate baseline is allowed to shift with an increase in the mean and/or change in the distribution of a climate variable, then significantly lower climatic conditions would be considered extreme based on a $5 \%$ statistical probability of occurrence (dark red shaded area, Figure 7 ). This statistically based outcome would occur even though periods of climatic extremity would be much more common from the system's organisms (i.e., red + dark red shaded areas, Figure 7) relative to the conditions they had experienced before. This illustrates the value of setting fixed climate baselines to identify extreme climatic conditions. A fixed reference set for a standard period-e.g., the pre-industrial global concentration of atmospheric $\mathrm{CO} 2$ of $280 \mathrm{ppm}$ - proved invaluable in studies of high atmospheric 
$\mathrm{CO} 2$ emissions. For extreme climate research, system-specific fixed climate baselines would provide the appropriate parameters for determining how extreme intensity and severity would change with current and future climate change scenarios and allow a more detailed assessment of when an extreme climate event will occur.

Climate extremes (e.g., those with a statistical probability of occurrence of $5 \%$; dark blue and yellow portions of the "present" climate curve; light blue and dark red parts of the "future" climate curve) are expected to become more frequent and violent with changes in climate context and/or changes in climate variables distribution (red shaded area). However, with a fixed climate baseline, this increase is detectable. The climate baseline will shift (arrow) with future climate change. Consequently, far fewer climate conditions would be considered extreme based on the statistical definition (dark red shaded area), and the system's species can undergo many more climatic extreme cycles (white + dark red shaded areas). Consequently, there is a strong need for ecological studies to create a fixed and standardized climate baseline-similar to that for atmospheric CO2 studies (e.g., c. 280 ppm)—to improve our ability to interpret how temperature conditions can be altered by future climate change and to understand its effect on ecological systems [6].

\section{Final Remarks and Outlook on Future Research}

Given the relatively recent expansion of interest in the topic of Chinese extreme weather events, a literature review was needed to take stock of the situation and contribute to a better understanding of the research structure. Our study made a significant improvement in the drought, flood, and landslide monitoring index, and the result could provide references for China's extreme weather events, which are useful for policy-making regarding climate change. This paper considers the effect of exaggerated vents on humans and the environment in China. Our study mentioned that more intense floods, drought, and landslides would happen in the future. A comprehensive analysis of impacts, consequences, and approaches to cope with extreme weather events was provided in this report in the human and environmental field. Despite the growing interest in extreme weather events, the findings of this work have shown that several gaps still need to be fulfilled. Furthermore, the empirical analysis findings suggest that future efforts will concentrate on flood events as they occur more often. The method used in this study required a high number of papers to be reviewed and research gaps to be identified. The availability of single words derived from the name, keywords, and abstract, on the other hand, does not provide the global perspective and lemma relationship. It also must be considered that the review of the text incorporates the definition of single words connected to other industries and is not applicable to the study's objectives.

When designating and implementing climate change adaptation and catastrophe risk management strategies and policies, more thought needs to be given to reducing severe occurrences and improving resilience to the adverse effects of events, promoting the sustainable development of society and the economy. Based on the information described in this study, high-priority regions can be defined for fast and significant advancement in enhancing knowledge of extreme weather and climate and creating adaptation policies for extreme events in China. The future adaptation and mitigation will be measured, including continuous development and maintenance of high-quality climate monitoring systems to enhance our ability to monitor and detect coming weather and climate changes. Efforts to digitize, homogenize, and evaluate long-term analyses of information findings to strengthen our trust in previous climate modifications. Weather observation systems should adhere to the observation norms that are compatible with climate and weather study communities, thus meeting the requirements to enhance the management capacity to detect observed changes in extreme climate. Establishing annual, regional-scale climate reconstructions for long-term historical records would support strengthening our understanding of regional climate variability in the very long-term period. Improvements of our knowledge of hurricane intensity mechanisms would lead to better short-term and long-term predictive capacities, and more comprehensive access to highly temporal (i.e., daily, hourly) information from previous and future climate model simulations to enable a better knowledge of the potential 
modifications in extreme weather and climate. Enhanced communication between the climate science community and those making climate-sensitive choices to improve our understanding and impact of climate extremes is necessary. A reliable database that connects extreme weather and climate change with their effects is needed, including damage and expenses under evolving socio-economic circumstances. Preparedness is the key to proactive planning measures for agricultural risk management, and weather and climate preparedness plans need to create and integrate comprehensive insurance and financial policies into their general long-term programs. Crop insurance is a significant choice for risk management. A safety net of emergency relief needs to be maintained to highlight the sound management of natural resources. It is necessary to coordinate the mix of preparedness programs and emergency reaction measures effectively, efficiently, and customer-oriented. The long-term approach is threefold: (i) preparedness to enhance response and restoration efficiency, such as by setting up early warning systems; (ii) mitigation measures to decrease the effect of pre-occurrence extreme occurrences or natural disasters; and (iii) adaptation strategies to prepare and manage the potential impacts of severe phenomena or natural disasters. Weather and climate understanding should be integrated into agricultural production planning and management choices. Sustainable, optimized production levels can be achieved by using weather and climate information effectively, while maintaining the integrity of the environment and minimizing degradation of soil, nutrients, and water bases. Lastly, technology (fertilizers, fresh seed varieties, and farming methods) should help manufacturing in the long run, but not damage the resource bases there.

Author Contributions: Conceptualization, R.A., A.K. and O.K.; Data curation, R.A.; Formal analysis, R.A. and A.K.; Supervision, O.K.; Writing-Original draft, R.A.; Writing-Review and editing, R.A., A.K. and O.K.; all authors collaborated in carrying out this research. All the authors read and accepted the final version of the manuscript. All authors have read and agreed to the published version of the manuscript.

Funding: The authors wish to sincerely thank the China Scholarship Council, China Three Gorges University, for funding this study. Alban Kuriqi received a Ph.D. grant by Fundação para a Ciência e a Tecnologia, I.P. (FCT), Portugal, under the Ph.D. Program FLUVIO-River Restoration and Management, grant number: $\mathrm{PD} / \mathrm{BD} / 114558 / 2016$.

Acknowledgments: The authors wish to thank the China Scholarship Council and China Three Gorges University.

Conflicts of Interest: The authors declare no conflict of interest.

\section{References}

1. Pachauri, R.K.; Allen, M.R.; Barros, V.R.; Broome, J.; Cramer, W.; Christ, R.; Church, J.A.; Clarke, L.; Dahe, Q.; Dasgupta, P. Climate Change 2014: Synthesis Report. Contribution of Working Groups I, II and III to the Fifth Assessment Report of the Intergovernmental Panel on Climate Change; IPCC: Geneva, Switzerland, 2014.

2. Field, C.B.; Barros, V.; Stocker, T.F.; Dahe, Q. Managing the Risks of Extreme Events and Disasters to Advance Climate Change Adaptation: Special Report of the Intergovernmental Panel on Climate Change; Cambridge University Press: Cambridge, UK, 2012.

3. Motha, R.P. The impact of extreme weather events on agriculture in the United States. In Challenges and Opportunities in Agrometeorology; Springer: Berlin/Heidelberg, Germany, 2011; pp. 397-407.

4. Vicca, S.; Balzarolo, M.; Filella, I.; Granier, A.; Herbst, M.; Knohl, A.; Longdoz, B.; Mund, M.; Nagy, Z.; Pintér, K. Remotely-sensed detection of effects of extreme droughts on gross primary production. Sci. Rep. 2016, 6, 28269. [CrossRef]

5. Cogato, A.; Meggio, F.; De Antoni Migliorati, M.; Marinello, F. Extreme Weather Events in Agriculture: A Systematic Review. Sustainability 2019, 11, 2547. [CrossRef]

6. Meehl, G.A.; Karl, T.; Easterling, D.R.; Changnon, S.; Pielke, R., Jr.; Changnon, D.; Evans, J.; Groisman, P.Y.; Knutson, T.R.; Kunkel, K.E. An introduction to trends in extreme weather and climate events: Observations, socioeconomic impacts, terrestrial ecological impacts, and model projections. Bull. Am. Meteorol. Soc. 2000, 81, 413-416. [CrossRef]

7. Wang, Y.-J.; Huang, J.-K.; Wang, J.-X. Household and community assets and farmers' adaptation to extreme weather event: The case of drought in China. J. Integr. Agric. 2014, 13, 687-697. [CrossRef] 
8. Chen, X.-L.; Liu, C.-G.; Wang, M.-M.; Zhou, Q. Causes of unusual distribution of coseismic landslides triggered by the Mw 6.1 2014 Ludian, Yunnan, China earthquake. J. Asian Earth Sci. 2018, 159, 17-23. [CrossRef]

9. Ding, G.; Li, X.; Li, X.; Zhang, B.; Jiang, B.; Li, D.; Xing, W.; Liu, Q.; Liu, X.; Hou, H. A time-trend ecological study for identifying flood-sensitive infectious diseases in Guangxi, China from 2005 to 2012. Environ. Res. 2019, 176, 108577. [CrossRef]

10. Griffiths, J.A.; Zhu, F.; Chan, F.K.S.; Higgitt, D.L. Modelling the impact of sea-level rise on urban flood probability in SE China. Geosci. Front. 2019, 10,363-372. [CrossRef]

11. $\mathrm{Xu}, \mathrm{C} . ; \mathrm{Xu}, \mathrm{X}$.; Shyu, J.B.H. Database and spatial distribution of landslides triggered by the Lushan, China Mw 6.6 earthquake of 20 April 2013. Geomorphology 2015, 248, 77-92. [CrossRef]

12. Yang, P.; Xia, J.; Zhang, Y.; Zhan, C.; Sun, S. How is the risk of hydrological drought in the Tarim River Basin, Northwest China? Sci. Total Environ. 2019, 693, 133555. [CrossRef]

13. Zhang, N.; Song, D.; Zhang, J.; Liao, W.; Miao, K.; Zhong, S.; Lin, S.; Hajat, S.; Yang, L.; Huang, C. The impact of the 2016 flood event in Anhui Province, China on infectious diarrhea disease: An interrupted time-series study. Environ. Int. 2019, 127, 801-809. [CrossRef]

14. Zhu, Y.; Xu, S.; Zhuang, Y.; Dai, X.; Lv, G.; Xing, A. Characteristics and runout behaviour of the disastrous 28 August 2017 rock avalanche in Nayong, Guizhou, China. Eng. Geol. 2019, 259, 105154. [CrossRef]

15. Leng, G.; Zhang, X.; Huang, M.; Asrar, G.R.; Leung, L.R. The role of climate covariability on crop yields in the conterminous United States. Sci. Rep. 2016, 6, 33160. [CrossRef]

16. Shiru, M.; Shahid, S.; Alias, N.; Chung, E.-S. Trend analysis of droughts during crop growing seasons of Nigeria. Sustainability 2018, 10, 871. [CrossRef]

17. Kuriqi, A. Assessment and Quantification of Meteorological Data for Implementation of Weather Radar in Mountainous Regions. Mausam 2016, 67, 789-802.

18. Alderman, K.; Turner, L.R.; Tong, S. Floods and human health: A systematic review. Environ. Int. 2012, 47, 37-47. [CrossRef] [PubMed]

19. Ardıçlığlu, M.; Kuriqi, A. Calibration of channel roughness in intermittent rivers using HEC-RAS model: Case of Sarimsakli creek, Turkey. SN Appl. Sci. 2019, 1. [CrossRef]

20. Kuriqi, A.; Ardiçlioğlu, M. Investigation of hydraulic regime at middle part of the Loire River in context of floods and low flow events. Pollack Period. 2018, 13, 145-156. [CrossRef]

21. Kuriqi, A.; Koçileri, G.; Ardiçlioğlu, M. Potential of Meyer-Peter and Müller approach for estimation of bed-load sediment transport under different hydraulic regimes. Model. Earth Syst. Environ. 2019. [CrossRef]

22. Kuriqi, A.; Ardiçlioglu, M.; Muceku, Y. Investigation of seepage effect on river dike's stability under steady state and transient conditions. Pollack Period. 2016, 11, 87-104. [CrossRef]

23. Huang, H.; Chen, X.; Zhu, Z.; Xie, Y.; Liu, L.; Wang, X.; Wang, X.; Liu, K. The changing pattern of urban flooding in Guangzhou, China. Sci. Total Environ. 2018, 622, 394-401. [CrossRef]

24. Sun, P.; Wen, Q.; Zhang, Q.; Singh, V.P.; Sun, Y.; Li, J. Nonstationarity-based evaluation of flood frequency and flood risk in the Huai River basin, China. J. Hydrol. 2018, 567, 393-404. [CrossRef]

25. Wang, Y.-J.; Gao, C.; Zhai, J.-Q.; Li, X.-C.; Hartmann, H. Spatio-temporal changes of exposure and vulnerability to floods in China. Adv. Clim. Chang. Res. 2014, 5, 197-205. [CrossRef]

26. Thomaz, E.L. The influence of traditional steep land agricultural practices on runoff and soil loss. Agric. Ecosyst. Environ. 2009, 130, 23-30. [CrossRef]

27. Zhang, Y.; Zhao, Y.; Liu, B.; Wang, Z.; Zhang, S. Rill and gully erosion on unpaved roads under heavy rainfall in agricultural watersheds on China's Loess Plateau. Agric. Ecosyst. Environ. 2019, 284. [CrossRef]

28. Xiao-jun, W.; Jian-yun, Z.; Shahid, S.; ElMahdi, A.; Rui-min, H.; Zhen-xin, B.; Ali, M. Water resources management strategy for adaptation to droughts in China. Mitig. Adapt. Strateg. Glob. Chang. 2012, 17, 923-937. [CrossRef]

29. Shahid, S.; Behrawan, H. Drought risk assessment in the western part of Bangladesh. Nat. Hazards 2008, 46, 391-413. [CrossRef]

30. Sordo-Ward, A.; Bejarano, M.; Iglesias, A.; Asenjo, V.; Garrote, L. Analysis of Current and Future SPEI Droughts in the La Plata Basin Based on Results from the Regional Eta Climate Model. Water 2017, 9. [CrossRef] 
31. Naumann, G.; Barbosa, P.; Garrote, L.; Iglesias, A.; Vogt, J. Exploring drought vulnerability in Africa: An indicator based analysis to be used in early warning systems. Hydrol. Earth Syst. Sci. 2014, 18, 1591-1604. [CrossRef]

32. Garrote, L.; Granados, A.; Iglesias, A. Strategies to reduce water stress in Euro-Mediterranean river basins. Sci Total Environ. 2016, 543, 997-1009. [CrossRef]

33. Garrote, L. Managing Water Resources to Adapt to Climate Change: Facing Uncertainty and Scarcity in a Changing Context. Water Resour. Manag. 2017, 31, 2951-2963. [CrossRef]

34. Liu, X.; Xu, X.; Yu, M.; Lu, J. Hydrological drought forecasting and assessment based on the standardized stream index in the Southwest China. Procedia Eng. 2016, 154, 733-737. [CrossRef]

35. Jia, J.-Y.; Han, L.-Y.; Liu, Y.-F.; He, N.; Zhang, Q.; Wan, X.; Zhang, Y.-F.; Hu, J.-M. Drought risk analysis of maize under climate change based on natural disaster system theory in Southwest China. Acta Ecol. Sin. 2016, 36, 340-349. [CrossRef]

36. Khan, N.; Shahid, S.; Ahmed, K.; Wang, X.; Ali, R.; Ismail, T.; Nawaz, N. Selection of GCMs for the projection of spatial distribution of heat waves in Pakistan. Atmos. Res. 2020, 233, 104688. [CrossRef]

37. Khan, N.; Shahid, S.; Chung, E.-S.; Kim, S.; Ali, R. Influence of Surface Water Bodies on the Land Surface Temperature of Bangladesh. Sustainability 2019, 11, 6754. [CrossRef]

38. Ali, K.; Abubaker, K. Long-Term Trends and Seasonality Detection of the Observed Flow in Yangtze River Using Mann-Kendall and Sen's Innovative Trend Method. Water 2019, 11. [CrossRef]

39. Ali, R.; Ismael, A.; Heryansyah, A.; Nawaz, N. Long Term Historic Changes in the Flow of Lesser Zab River, Iraq. Hydrology 2019, 6. [CrossRef]

40. Ali, R.; Kuriqi, A.; Abubaker, S.; Kisi, O. Hydrologic Alteration at the Upper and Middle Part of the Yangtze River, China: Towards Sustainable Water Resource Management Under Increasing Water Exploitation. Sustainability 2019, 11. [CrossRef]

41. Sediqi, M.N.; Shiru, M.S.; Nashwan, M.S.; Ali, R.; Abubaker, S.; Wang, X.; Ahmed, K.; Shahid, S.; Asaduzzaman, M.; Manawi, S.M.A. Spatio-Temporal Pattern in the Changes in Availability and Sustainability of Water Resources in Afghanistan. Sustainability 2019, 11, 5836. [CrossRef]

42. Timofeev, A.; Sterin, A. Using the quantile regression method to analyze changes in climate characteristics. Russ. Meteorol. Hydrol. 2010, 35, 310-319. [CrossRef]

43. Guo, E.; Liu, X.; Zhang, J.; Wang, Y.; Wang, C.; Wang, R.; Li, D. Assessing spatiotemporal variation of drought and its impact on maize yield in Northeast China. J. Hydrol. 2017, 553, 231-247. [CrossRef]

44. Zhao, S.; Cong, D.; He, K.; Yang, H.; Qin, Z. Spatial-temporal variation of drought in China from 1982 to 2010 based on a modified temperature vegetation drought index (mTVDI). Sci. Rep. 2017, 7, 17473. [CrossRef] [PubMed]

45. Muceku, Y.; Korini, O.; Kuriqi, A. Geotechnical Analysis of Hill's Slopes Areas in Heritage Town of Berati, Albania. Period. Polytech. Civ. Eng. 2016, 60, 61-73. [CrossRef]

46. Hungr, O.; Leroueil, S.; Picarelli, L. The Varnes classification of landslide types, an update. Landslides 2014, 11, 167-194. [CrossRef]

47. Bai, S.; Wang, J.; Zhang, Z.; Cheng, C. Combined landslide susceptibility mapping after Wenchuan earthquake at the Zhouqu segment in the Bailongjiang Basin, China. Catena 2012, 99, 18-25. [CrossRef]

48. Cao, J.; Zhang, Z.; Wang, C.; Liu, J.; Zhang, L. Susceptibility assessment of landslides triggered by earthquakes in the Western Sichuan Plateau. Catena 2019, 175, 63-76. [CrossRef]

49. Qi, S.; Xu, Q.; Lan, H.; Zhang, B.; Liu, J. Spatial distribution analysis of landslides triggered by 2008.5 .12 Wenchuan Earthquake, China. Eng. Geol. 2010, 116, 95-108. [CrossRef]

50. Xing, A.; Wang, G.; Yin, Y.; Jiang, Y.; Wang, G.; Yang, S.; Dai, D.; Zhu, Y.; Dai, J. Dynamic analysis and field investigation of a fluidized landslide in Guanling, Guizhou, China. Eng. Geol. 2014, 181, 1-14. [CrossRef]

51. Jiang, S.; Wen, B.-P.; Zhao, C.; Li, R.-D.; Li, Z.-H. Kinematics of a giant slow-moving landslide in Northwest China: Constraints from high resolution remote sensing imagery and GPS monitoring. J. Asian Earth Sci. 2016, 123, 34-46. [CrossRef]

52. Ma, F.; Ye, A.; You, J.; Duan, Q. 2015-2016 floods and droughts in China, and its response to the strong El Niño. Sci. Total Environ. 2018, 627, 1473-1484. [CrossRef]

53. Zhang, Y.; Wang, Y.; Chen, Y.; Liang, F.; Liu, H. Assessment of future flash flood inundations in coastal regions under climate change scenarios-A case study of Hadahe River basin in northeastern China. Sci. Total Environ. 2019, 693, 133550. [CrossRef] 
54. Xu, K.; Yang, D.; Yang, H.; Li, Z.; Qin, Y.; Shen, Y. Spatio-temporal variation of drought in China during 1961-2012: A climatic perspective. J. Hydrol. 2015, 526, 253-264. [CrossRef]

55. Yang, G.; Shao, W.; Wang, H.; Han, D. Drought evolution characteristics and attribution analysis in northeast China. Procedia Eng. 2016, 154, 749-756. [CrossRef]

56. Lin, Q.; Wang, Y. Spatial and temporal analysis of a fatal landslide inventory in China from 1950 to 2016. Landslides 2018, 15, 2357-2372. [CrossRef]

57. Liu, X.; Miao, C. Large-scale assessment of landslide hazard, vulnerability and risk in China. Geomat. Nat. Hazards Risk 2018, 9, 1037-1052. [CrossRef]

58. Tang, C.; Ma, G.; Chang, M.; Li, W.; Zhang, D.; Jia, T.; Zhou, Z. Landslides triggered by the 20 April 2013 Lushan earthquake, Sichuan Province, China. Eng. Geol. 2015, 187, 45-55. [CrossRef]

59. Zhao, S.; Chigira, M.; Wu, X. Buckling deformations at the 2017 Xinmo landslide site and nearby slopes, Maoxian, Sichuan, China. Eng. Geol. 2018, 246, 187-197. [CrossRef]

60. Ayantobo, O.O.; Li, Y.; Song, S.; Yao, N. Spatial comparability of drought characteristics and related return periods in mainland China over 1961-2013. J. Hydrol. 2017, 550, 549-567. [CrossRef]

61. Liu, Z.; Li, C.; Zhou, P.; Chen, X. A probabilistic assessment of the likelihood of vegetation drought under varying climate conditions across China. Sci. Rep. 2016, 6, 35105. [CrossRef]

62. Wang, S.; Mo, X.; Hu, S.; Liu, S.; Liu, Z. Assessment of droughts and wheat yield loss on the North China Plain with an aggregate drought index (ADI) approach. Ecol. Indic. 2018, 87, 107-116. [CrossRef]

63. Wu, J.; Zhou, L.; Liu, M.; Zhang, J.; Leng, S.; Diao, C. Establishing and assessing the Integrated Surface Drought Index (ISDI) for agricultural drought monitoring in mid-eastern China. Int. J. Appl. Earth Obs. Geoinf. 2013, 23, 397-410. [CrossRef]

64. Zhao, P.; Lü, H.; Yang, H.; Wang, W.; Fu, G. Impacts of climate change on hydrological droughts at basin scale: A case study of the Weihe River Basin, China. Quat. Int. 2019, 513, 37-46. [CrossRef]

65. Cong, D.; Zhao, S.; Chen, C.; Duan, Z. Characterization of droughts during 2001-2014 based on remote sensing: A case study of Northeast China. Ecol. Inform. 2017, 39, 56-67. [CrossRef]

66. Pradhan, N.S.; Fu, Y.; Zhang, L.; Yang, Y. Farmers' perception of effective drought policy implementation: A case study of 2009-2010 drought in Yunnan province, China. Land Use Policy 2017, 67, 48-56. [CrossRef]

67. Xu, P.; Zhou, T.; Zhao, X.; Luo, H.; Gao, S.; Li, Z.; Cao, L. Diverse responses of different structured forest to drought in Southwest China through remotely sensed data. Int. J. Appl. Earth Obs. Geoinf. 2018, 69, 217-225. [CrossRef]

68. Zhang, D.; Chen, P.; Zhang, Q.; Li, X. Copula-based probability of concurrent hydrological drought in the Poyang lake-catchment-river system (China) from 1960 to 2013. J. Hydrol. 2017, 553, 773-784. [CrossRef]

69. Sun, F.; Mejia, A.; Zeng, P.; Che, Y. Projecting meteorological, hydrological and agricultural droughts for the Yangtze River basin. Sci. Total Environ. 2019, 696, 134076. [CrossRef]

70. Xu, K.; Yang, D.; Xu, X.; Lei, H. Copula based drought frequency analysis considering the spatio-temporal variability in Southwest China. J. Hydrol. 2015, 527, 630-640. [CrossRef]

71. Zhang, H.; Chang, J.; Gao, C.; Wu, H.; Wang, Y.; Lei, K.; Long, R.; Zhang, L. Cascade hydropower plants operation considering comprehensive ecological water demands. Energy Convers. Manag. 2019, 180, 119-133. [CrossRef]

72. Yang, H.; Wang, H.; Fu, G.; Yan, H.; Zhao, P.; Ma, M. A modified soil water deficit index (MSWDI) for agricultural drought monitoring: Case study of Songnen Plain, China. Agric. Water Manag. 2017, 194, 125-138. [CrossRef]

73. Song, L.; Li, Y.; Ren, Y.; Wu, X.; Guo, B.; Tang, X.; Shi, W.; Ma, M.; Han, X.; Zhao, L. Divergent vegetation responses to extreme spring and summer droughts in Southwestern China. Agric. For. Meteorol. 2019, 279, 107703. [CrossRef]

74. Sun, S.; Li, Q.; Li, J.; Wang, G.; Zhou, S.; Chai, R.; Hua, W.; Deng, P.; Wang, J.; Lou, W. Revisiting the evolution of the 2009-2011 meteorological drought over Southwest China. J. Hydrol. 2019, 568, 385-402. [CrossRef]

75. Huang, S.; Ye, G.; Lin, J.; Chen, K.; Xu, X.; Ruan, H.; Tan, F.; Chen, H.Y. Autotrophic and heterotrophic soil respiration responds asymmetrically to drought in a subtropical forest in the Southeast China. Soil Biol. Biochem. 2018, 123, 242-249. [CrossRef]

76. Gong, L.; Hou, S.; Su, B.; Miao, K.; Zhang, N.; Liao, W.; Zhong, S.; Wang, Z.; Yang, L.; Huang, C. Short-term effects of moderate and severe floods on infectious diarrheal diseases in Anhui Province, China. Sci. Total Environ. 2019, 675, 420-428. [CrossRef] [PubMed] 
77. Kai, W.; Deyi, C.; Zhaohui, Y. Flood control and management for the transitional Huaihe River in China. Procedia Eng. 2016, 154, 703-709. [CrossRef]

78. Lyu, H.-M.; Xu, Y.-S.; Cheng, W.-C.; Arulrajah, A. Flooding hazards across southern China and prospective sustainability measures. Sustainability 2018, 10, 1682. [CrossRef]

79. Liu, Z.; Ding, G.; Zhang, Y.; Lao, J.; Liu, Y.; Zhang, J.; Lu, L.; Liu, Q.; Jiang, B. Identifying different types of flood-sensitive diarrheal diseases from 2006 to 2010 in Guangxi, China. Environ. Res. 2019, 170, 359-365. [CrossRef]

80. Liu, X.; Liu, Z.; Ding, G.; Jiang, B. Projected burden of disease for bacillary dysentery due to flood events in Guangxi, China. Sci. Total Environ. 2017, 601, 1298-1305. [CrossRef]

81. Wu, H.-L.; Cheng, W.-C.; Shen, S.-L.; Lin, M.-Y.; Arulrajah, A. Variation of hydro-environment during past four decades with underground sponge city planning to control flash floods in Wuhan, China: An overview. Undergr. Space 2019. [CrossRef]

82. Fan, W.; Lv, J.; Cao, Y.; Shen, M.; Deng, L.; Wei, Y. Characteristics and block kinematics of a fault-related landslide in the Qinba Mountains, western China. Eng. Geol. 2019, 249, 162-171. [CrossRef]

83. Leng, Y.; Peng, J.; Wang, Q.; Meng, Z.; Huang, W. A fluidized landslide occurred in the Loess Plateau: A study on loess landslide in South Jingyang tableland. Eng. Geol. 2018, 236, 129-136. [CrossRef]

84. Liu, W.; Yan, S.; He, S. Landslide damage incurred to buildings: A case study of Shenzhen landslide. Eng. Geol. 2018, 247, 69-83. [CrossRef]

85. Mi, J.; Liu, R.; Zhang, S.; Hou, H.; Yang, Y.; Chen, F.; Zhang, L. Vegetation patterns on a landslide after five years of natural restoration in the Loess Plateau mining area in China. Ecol. Eng. 2019, 136, 46-54. [CrossRef]

86. $\mathrm{Xu}, \mathrm{S}$.; Niu, R. Displacement prediction of Baijiabao landslide based on empirical mode decomposition and long short-term memory neural network in Three Gorges area, China. Comput. Geosci. 2018, 111, 87-96. [CrossRef]

87. Zhang, S.; Xu, Q.; Hu, Z. Effects of rainwater softening on red mudstone of deep-seated landslide, Southwest China. Eng. Geol. 2016, 204, 1-13. [CrossRef]

88. Li, M.; Zhang, L.; Dong, J.; Tang, M.; Shi, X.; Liao, M.; Xu, Q. Characterization of pre-and post-failure displacements of the Huangnibazi landslide in Li County with multi-source satellite observations. Eng. Geol. 2019, 257, 105140. [CrossRef]

89. Sun, Q.; Zhang, L.; Ding, X.; Hu, J.; Li, Z.; Zhu, J. Slope deformation prior to Zhouqu, China landslide from InSAR time series analysis. Remote Sens. Environ. 2015, 156, 45-57. [CrossRef]

90. Li, G.; Lei, Y.; Yao, H.; Wu, S.; Ge, J. The influence of land urbanization on landslides: An empirical estimation based on Chinese provincial panel data. Sci. Total Environ. 2017, 595, 681-690. [CrossRef]

91. Huang, D.; Li, Y.Q.; Song, Y.X.; Xu, Q.; Pei, X.J. Insights into the catastrophic Xinmo rock avalanche in Maoxian county, China: Combined effects of historical earthquakes and landslide amplification. Eng. Geol. 2019, 258, 105158. [CrossRef]

92. Li, Z.-Y.; Huang, X.-H.; Yu, D.; Su, J.-R.; Xu, Q. Broadband-seismic analysis of a massive landslide in southwestern China: Dynamics and fragmentation implications. Geomorphology 2019, 336, 31-39. [CrossRef]

93. Fan, X.; Zhan, W.; Dong, X.; van Westen, C.; Xu, Q.; Dai, L.; Yang, Q.; Huang, R.; Havenith, H.-B. Analyzing successive landslide dam formation by different triggering mechanisms: The case of the Tangjiawan landslide, Sichuan, China. Eng. Geol. 2018, 243, 128-144. [CrossRef]

94. Chen, K.-T.; Wu, J.-H. Simulating the failure process of the Xinmo landslide using discontinuous deformation analysis. Eng. Geol. 2018, 239, 269-281. [CrossRef]

95. Tang, M.; Xu, Q.; Yang, H.; Li, S.; Iqbal, J.; Fu, X.; Huang, X.; Cheng, W. Activity law and hydraulics mechanism of landslides with different sliding surface and permeability in the Three Gorges Reservoir Area, China. Eng. Geol. 2019, 260, 105212. [CrossRef]

96. Liu, G.; Guo, H.; Perski, Z.; Fan, J.; Bai, S.; Yan, S.; Song, R. Monitoring the slope movement of the Shuping landslide in the Three Gorges Reservoir of China, using X-band time series SAR interferometry. Adv. Space Res. 2016, 57, 2487-2495. [CrossRef]

97. Hong, H.; Ilia, I.; Tsangaratos, P.; Chen, W.; Xu, C. A hybrid fuzzy weight of evidence method in landslide susceptibility analysis on the Wuyuan area, China. Geomorphology 2017, 290, 1-16. [CrossRef]

98. Luo, J.; Pei, X.; Evans, S.G.; Huang, R. Mechanics of the earthquake-induced Hongshiyan landslide in the 2014 Mw 6.2 Ludian earthquake, Yunnan, China. Eng. Geol. 2019, 251, 197-213. [CrossRef] 
99. Li, M.; Zhang, L.; Shi, X.; Liao, M.; Yang, M. Monitoring active motion of the Guobu landslide near the Laxiwa Hydropower Station in China by time-series point-like targets offset tracking. Remote Sens. Environ. 2019, 221, 80-93. [CrossRef]

100. Zhao, Y.; Wang, R.; Jiang, Y.; Liu, H.; Wei, Z. GIS-based logistic regression for rainfall-induced landslide susceptibility mapping under different grid sizes in Yueqing, Southeastern China. Eng. Geol. 2019, 105147. [CrossRef]

101. Gao, Y.; Yin, Y.; Li, B.; He, K.; Wang, X. Post-failure behavior analysis of the Shenzhen "12.20" CDW landfill landslide. Waste Manag. 2019, 83, 171-183. [CrossRef]

102. Přívara, A.; Přívarová, M. Nexus between Climate Change, Displacement and Conflict: Afghanistan Case. Sustainability 2019, 11, 5586. [CrossRef]

103. Wong, L. China's urban migrants-the public policy challenge. Pac. Aff. 1994, 67, 335-355. [CrossRef]

104. Deng, Q. Natural disasters, migration and urban insecurity in China. In Proceedings of the Interconnection among Global Problems in Northeast Asia Workshop, Paju, Korea, 16-17 March 2009.

105. Pei, Q. Migration for survival under natural disasters: A reluctant and passive choice for agriculturalists in historical China. Sci. China Earth Sci. 2017, 60, 2089-2096. [CrossRef]

106. Vina, A.; Chen, X.; McConnell, W.J.; Liu, W.; Xu, W.; Ouyang, Z.; Zhang, H.; Liu, J. Effects of natural disasters on conservation policies: The case of the 2008 Wenchuan Earthquake, China. Ambio 2011, 40, 274-284. [CrossRef] [PubMed]

107. McCarthy, J.J.; Canziani, O.F.; Leary, N.A.; Dokken, D.J.; White, K.S. Climate change 2001: Impacts, adaptation, and vulnerability: Contribution of Working Group II to the third assessment report of the Intergovernmental Panel on Climate Change; Cambridge University Press: Cambridge, UK, 2001; Volume 2.

108. Schöfberger, I. Environmental change and translocal vulnerability in Senegal. Ger. Dev. Inst. Dtsch. Inst. Entwickl. Migr. Environ. Clim. Chang. Policy Brief Ser. 2018, 3, 1-8.

109. Smith, M.D. An ecological perspective on extreme climatic events: A synthetic definition and framework to guide future research. J. Ecol. 2011, 99, 656-663. [CrossRef]

(C) 2020 by the authors. Licensee MDPI, Basel, Switzerland. This article is an open access article distributed under the terms and conditions of the Creative Commons Attribution (CC BY) license (http://creativecommons.org/licenses/by/4.0/). 